\title{
LIBERDADES FUNDAMENTAIS DA PESSOA HUMANA EM FACE DO ESTADO (*)
}

\author{
Ary Florencio Guimarães
}

1. Sub-Procurador Geral do Estado e Prof. da Faculdade de Direito de Curitiba

\section{S U MÁR I O}

I - Origem etimológica da palavra "pessoa". II - Conceito filosófico. Definuições de BOECIO e S. TOMAZ DE AQUINO. III - A pessoa é fim e não meio. FARIAS BRITO e KANT. IV - Evolução histórica. Os direitos do homem na órbita internacional. Preeminência dos direitos sociais. A ONU. $V$ - A natureza humanistica do direito. A coexistência social. $O$ homem como sujeito de direitos e obrigações. VI - A sociabilidade humana. Da família ao Estado. VII - O Estado é meio e não fim. Liberdade e autoridade. VIII - Equilíbrio entre a liberdade e a autoridade. A ordem jurídica e a vida social. IX - A Constituição como lei fundamental. Os direitos da pessoa humana preexistentes ao Estado. $X$ - A liberdade e os seus justos limites. Conceitos. XI - As garantias das liberdades fundamentais do homem. XII - Os direitos absolutos e os relativos. XIII - O princípio da superlegalidade constitucional como baluarte das liberdades públicas. Hierarquia das leis. XIV - A teoria da distinção dos poderes do Estado. XV - A irretroatividade da lei e o respeito aos direitos adquiridos. $X V I$ - Do regime representativo. Corolários do direito de sufrágio. XVII - $O$ habeas-corpus, 0 mandado de segurança e o dogma do "nullum crimen, nulla poena sine lege". XVIII - Princípios informativos da justiça criminal quanto à pessoa do acusado. XIX - A ação popular no direito brasileiro. $X X$ - As linhas estruturais da Rep. dos EE. Unidos do Brasil na Constituição de 1946. XXI - Os totalitarismos: regimes incompativeis com a dignidade da pessoa humana. $X X I I$ - A democracia como meio ideal para o desenvolvimento do homem e do cidadão. XXIII - Conclusões.

(*) Tese apresentada ao I Congresso Interamericano do Ministério Público, realizado em São Paulo, no período de 21 a 27 de novembro de 1954, por motivo da passagem do IV Centenário de fundação da capital do vizinho Estado. 
1. O vocábulo pessoa, segundo os dicionaristas, vem do latim persona, tendo sido tomado ao teatro e aplicado, por metáfora, à linguagem do Direito. JONATAS SERRANO, depois de referir que da idéia do eu decorre a de pessoa e, desta, a de personalidade jurídica, abona a assertiva, acentuando que 0 vocábulo, na sua origem etimológica,

"lembra a máscara usada na comédia ou no drama para reforçar (personare) a voz dos autores. Personam tragicam forte vulpes viderat, lê-se em FEDRO. Como havia para certas personagens tipos invariàveis, fácil era reconhecê-los graças à máscara. Personam agere era, pois, representar um papel. Ora, também o homem representa de certo modo vários papéis na cena jurídica (pai, filho, espôso, etc.). Daí a translação de sentido. Pessoa é, portanto, o homem, o eu psicológico, o ser consciente e livre, capaz de direitos e obrigações. Todo homem é pessoa e só o homem o é. Hoje ninguém contesta isso; mas por longos séculos a escravidão reduziu milhares de seres humanos à categoria de coisas, de simples máquinas, de míseras bestas de cargas, desconhecendo o caráter inviolável da personalidade". (Filosofia do Direito, 3. ${ }^{a}$ ed., revista e atualizada, p. 52).

Não é diverso, no sentido etimológico, o ensinamento de ALFREDO ORGAZ, catedrático de Direito Civil da Universidade de Córdoba, na vizinha República Argentina:

"Para explicar gràficamente el concepto jurídico de "persona", es todavía muy útil recordar el origen de 
la palabra. Entre las diversas explicaciones que se han formulado, es la más admitida la que vincula el origen de la palabra al lenguaje teatral; según esta hipótese, en las representaciones teatrales de la antigüedad "persona" se llamaba la máscara con que el actor se cubría el rostro para representar su papel en el drama. Esta máscara tenía por objeto hacer resonar (personare) la voz y, además, no era individual sino típica del papel que el actor desempenaba en la obra, de modo que la misma máscara servía siempre para caracterizar el mismo papel; de aquí que, por una simple extensión, la palabra sirviera después para aludir, asimismo, al actor enmascarado, esto es, al "personaje". Del teatro pasó la palabra al lenguaje común y fué empleada, con significación análoga, para referirse a la función e a la cualidad que investía cada individuo en la vida. En fin, por una serie de mutaciones sucesivas, la palabra ha terminado por designar simplemente al hombre, al "individuo de la especie humana". (Derecho Civil Argentino - PERSONAS INDIVIDUALES, Buenos Aires, 1946, ps. 8-9).

A origem da palavra, todavia, não se acha estabelecida extreme de dúvidas.

A maioria dos estudiosos entende que ela vem do latim, como já ficou exposto no limiar destas páginas. Outros, porém, remontam a sua fonte ao grego. E existe, ainda, uma terceira corrente, que admite que a palavra pessoa derivaria do etrusco, cuja civilização teve, como é sabido, grande influência sôbre a de Roma. O Professor PIERRE RUFFEL, partidário desta última explicação, segundo ALFREDO ORGAZ, esclarece que

"la palabra etrusca phersu designa la máscara de teatro, no enteramente individual sino típica, tal carácter, tal función. Se cree que la palabra ha pasado del etrusco al latín con el subfijo que se agrega a la declinación, de onde persona"; citado por EUGÈNE 
DUTHOIT, en el libro La personne humaine en péril, Cursos y Conferencias de las Semanas Sociales de Francia, ps. 43 y 44 (Lyon). El mismo origen etrusco había sido indicado por SKUTSCH, citado por FERRARA". (Op. cit., p. 9.).

2. A. MACHADO PAUPERIO, doutrinando com propriedade, quer sob o aspecto etimológico, quer sob o filosófico, faz precisa distinção entre indivíduo e pessoa, esclarecendo que,

“evidentemente, a noção de pessoa não foi conhecida da antiguidade. $\mathrm{O}$ vocábulo persona, no idioma latino, não é, inicialmente, senão a máscara do ator. Etimològicamente, derivar-se-ia tal palavra, segundo AULO GÉLIO, de personare, que significa retumbar. Com o tempo, de máscara do ator, passou a designar o vocábulo o próprio autor, isto é, o indivíduo que representava um determinado papel. Daí veio personalidade. Afinal, como diz MASPETIOL (L'Etat devant la personne et la société, p. 146), no século VI passou a palavra pessoa a ganhar um significado novo, através da conhecida definição de BOECIO: Persona est substantia individua rationalis naturae. No homem, portanto, podemos distinguir o indivíduo e a pessoa". (Teoria Geral do Estado, Rio 1953, p. 246).

Essa definição foi posteriormente esquadrinhada por S. TOMAZ DE AQUINO, cujos conceitos deram margem a uma fécunda especulação filosófica, encetada pela Escolástica a respeito do problema da pessoa (Persona significat id quod est perfectissimum in toda natura, scilicet subsistens in rationali natura - Suma Teológica, I, q., 29, a. 3).

Daí, afirmarem os doutores e teólogos serem três as características essenciais da pessoa. A saber:

$1 .^{\mathrm{a}}$ - substancialidade (a pessoa é um composto de corpo e alma) ; $2 .^{a}$ - individualidade (na pessoa es- 
tá individualizada a humanidade); e $3 .^{\mathrm{a}}$ - racionalidade (a pessoa é consciente e livre).

A pessoa, nessas condições, é aquele ser perfeitíssimo do mundo criado, a que se refere S. TOMAZ DE AQUINO, ser composto de matéria e espírito, "verdadeiro microcosmo, um autêntico universo particularizado sob a forma individual".

É oportuna, aqui, a dissertação de A. MACHADO PAUPERIO sôbre a distinção entre indivíduo e pessoa, não só em face da sociedade, como do Estado:

"Como indivíduo, o homem é apenas átomo do organismo social e, como a parte se deve subordinar lògicamente ao todo, deve o homem, nessa qualidade, subordinar-se à sociedade, sacrificando mesmo, se preciso fôr, o seu bem individual ao bem maior da coletividade. Mas, parte da sociedade, é também o homem pessoa, isto é, realidade espiritual individuada e distinta. Nessa qualidade, é êle dotado de direitos inatos, inalienáveis e imprescritíveis, que deve o próprio Estado respeitar". (Op. cit., p. 246).

3. Apreciando a moral de KANT, de dignificação da pessoa humana, em nós mesmos, e nos outros, como sendo o primacial fundamento de tôda a filosofia jurídica do grande mestre, que definiu o Direito como o conjunto das condições que limitam as liberdades para tornar possível o seu acôrdo, FARIAS BRITO esclarece com brilhantismo:

“A pessoa é inviolável, por isto tem direitos; e entre êstes o direito por excelência, o direito supremo é a liberdade. Mas por que a pessoa é inviolável? Porque o homem não é um meio, mas um fim. É a significação do princípio da humanidade considerada como fim em si. KANT se explica assim: "O homem e tôda criatura racional, existe como fim em si, e não como meio para o uso arbitrário de tal vontade". Há, pois, de um lado, aquilo que se nos apresenta co- 
mo meio para as nossas ações ou condições para a satisfação das nossas inclinações ou necessidades, isto é, as coisas, o objeto do direito; e, de outro lado, aquilo que constitui um fim em si, nem se pode compreender como meio para qualquer outro fim, isto é, as pessoas, o princípio, o sujeito mesmo do direito. Quer isto dizer: de tudo nos podemos servir como meio para a satisfação de nossas necessidades, menos do homem, porque o homem não é um meio, mas um fim em si. Dêste modo as coisas são de valor relativo, condicional, e delas nos podemos servir livremente; mas as pessoas, não; são de valor absoluto e não se podem servir umas das outras como instrumentos ou meios, devendo-se, pelo contrário, mútuo respeito. É a significação desta outra fórmula de KANT: "Obra de tal modo que sempre trates a humanidade, já na tua pessoa, já na pessoa dos outros, como um fim, e que nunca dela te sirvas como um meio". ( $A$ verdade como regra das ações, 2. ${ }^{a}$ ed., 1953, ps. 134-135).

De qualquer maneira, porém, só o homem é verdadeiramente pessoa, "isto é, ser consciente e livre, capaz de direitos e obrigações; porque só êle possue a razão, graças à qual distingue o bem e o mal, o justo e o injusto, o. contingente e o absoluto, as causas dos fenômenos e os princípios superiores que devem reger a própria atividade humana". (JONATHAS SERRANO, op. cit., p. 79).

0 homem nunca deixa de ser homem, qualquer que seja a sua posição, quer em face do seu semelhante, quer em face da sociedade, quer em face do Estado. Daí, a conhecida afirmativa de AHRENS: "O homem permanece homem e como tal deve ser considerado e respeitado em tôdas as situações da vida". (Traité de Philosophie, v. II, p. 18). A razão, inerente à personalidade do homem, como uma de suas principais características, é um atributo de indisponibilidade absoluta e que o faz distinguir, como dissemos, o bem do mal, o justo do injusto. 
SORTAIS, por isso mesmo, perguntando e, ao mesmo tempo, respondendo, no-lo diz, de modo cabal e irretorquível:

"Quem aceitaria tôdas as riquezas e todos os prazeres imagináveis, com a condição apenas de ficar privado da razão? Logo, o homem nada pode colocar acima de sua personalidade; deve, porém, sacrificar-lhe tudo... cumpre tomá-la sempre como objetivo e tratá-la sempre como um fim". E judiciosamente conclue JONATHAS SERRANO, apoiando o seu assêrto em VAREILLES -SOMMIERES (Les Principes fondamentaux du Droit, p. 23), em BOUCAUD (L'Idée du Droit et son évolution historique, ps. 2930) e no mesmo SORTAIS (Traité de Philosophie, II, ps. 60-61) : "Daí deflue que nenhum homem pode ser considerado como simples coisa, objeto ou meio. A personalidade é a razão de ser próxima da capacidade de direito". (Op. cit., p. 80).

Assim, o homem não pode ser escravo nem do próprio homem, nem tampouco de grupos de homens, e, muito menos, do próprio Estado.

4. Lenta, porém evolutiva, tem sido a marcha da civilização na conquista das liberdades fundamentais da pessoa humana em face do Estado.

A antiguidade, franca adepta da escravidão, desconhecia quase que completamente os direitos essenciais inerentes ao ser humano.

Grécia e Roma, afora uns conteúdos de liberdade política, ofereciam, na verdade, um esplendor de absolutismo estatal, relegados, que eram, à condição de escravos, não os vencidos na guerra, como também os que se achavam agrilhoados pela mais vil e abjeta servidão. $O$ homem, na antiguidade, ou era cidadão livre, ou era escravo. E quando era escravo, não se lhe dava qualquer direito, quer de ordem política, quer de ordem pessoal. 
Nas polis espartanas e atenienses ou nas civitas romanas o escravo, em suma, estava atirado à simples e ignóbil condição de coisa, de mercadoria, e não de homem!

O Estado antigo era, assim, orgânica e politicamente, um todo absolutista e despótico. (Cf. FUSTEL DE COULANGES, A Cidade Antiga, v. $1 .^{\circ}$, ps. $342-348$ )

O cristianismo evangelizador surgiu, como uma luz, dentro dessa imensa treva. Veio o Cristo e pregou o amor. Pregou a fraternidade entre os homens e os povos. E pregou a caridade, a igualdade de todos, ao invés do ódio ao estrangeiro, ou do desprêzo votado aos escravos, mitigando, dessa forma, a onda absolutista do Estado. Surgiu, então, no mundo, a primeira e frutuosa semente em prol da limitação do poder do Príncipe: "Dai a Cesar o que é de Cesar; dai a Deus o que é de Deus". Limitação, não há negar, do poder estatal, que abarcava, na época, o comando, não só da vida temporal, como também da vida espiritual dos cidadãos.

E a luta prosseguiu. Luta afanosa, pacífica às vêzes, sanguinolenta quase sempre, em busca de uma nova forma de vida política e social, que garantisse o homem diante do poder público.

O feudalismo, decorrente da repartição do colosso romano que se esboreara, trouxe o contratualismo em tôrno da bleba: os homens fracos eram protegidos pelos fortes, na categoria de servos, dando-lhes, em troca, o seu trabalho e a sua liberdade de ação. As opressões continuavam...

O excesso de autoridade, ora por parte dos suzeranos (pequenos reis dentro dos seus feudos), ora por parte dos monarcas, era uma evidência ofuscante. A autoridade, dessa forma, não tinha limites. A sua demasia era a regra geral, imperando coercitivamente sôbre povos e indivíduos.

Os direitos do homem, como ser racional e livre, começaram, porém, a surgir perante o Govêrno, que é o "Estado em ação". (FAIRCHILD - Dictionary of Sociology, New York, 1944, p. 132). 
DARCY AZAMBUJA declara que "foi na Inglaterra que a liberdade política e a igualdade civil se manifestaram no mundo moderno como condições indispensáveis à vida social". (Teoria Geral do Estado, p. 158).

Com efeito, a "Magna Charta Libertatum", jurada por João Sem Terra, em 1215, apareceu como a pedra de toque do reconhecimento formal de alguns direitos fundamentais, inerentes à personalidade eminente do homem, diante do poderio. da realeza então imperante, transformando-se numa autêntica e generosa conquista que impunha limitações à autoridade do monarca.

AZAMBUJA acrescenta :

“O $\$ 12$ (da Magna Carta) dispõe: "Nenhum impồto ou obrigação será estabelecido senão pelo conselho do reino (composto de barões e prelados). Era, como diz LAPRADELLE, o primeiro fundamento da liberdade política. 0 § 39 declarava: "Nenhum homem livre poderá ser prêso, detido, privado de seus bens, pôsto fora da lei ou exilado sem julgamento de seus pares ou por disposição de lei". Era o primeiro fundamento da liberdade civil". (Op. cit., p. 158).

Gradativamente foi o povo inglês completando a obra inicial de liberdade política e civil. O aparecimento dos "bill of rights" (no século XVII) e da "lei de estabelecimento" em 1701 constituiram, sem dúvida, novas declarações de direitos individuais diante do Estado, porque sempre limitativas da desmesurada autoridade real. Tais conquistas libertárias devem-se, é certo, à ação do Parlamento, que a miúde se insurgia contra o despotismo real. A Inglaterra, como ainda no-lo adianta AZAMBUJA, nessa "longa e tenaz luta faria jus à glória de ter sido a pátria dos direitos do homem". (0p. cit., p. 159).

Outro marco significativo, no dealbar das liberdades fundamentais asseguradas pelo Estado ao homem, vamos encontrar no solo americano, por intermédio da famosa Declaração de Virgínia, assinada pelas 13 Colônias, em Williamsburgh, aos dôze de junho de 1776, e que foi como que um alargamento dos 
princípios de liberdade, já fixados na Constituição de Rhode Island, em 1663. No ano de 1787, com a Constituição Federal dos Estados Unidos da América (emendada, em 1789, para 0 fim de expressa declaração de direitos), a grande nação do norte aumentava o rol das prerrogativas do homem.

Logo a seguir, na Europa, o povo de França, em meio da agitação revolucionária, que destronou e aniquilou o predomínio monárquico dos Luízes, de 18 a 27 de agôsto de 1789, decisivamente influenciado pelas idéias de JEAN JACQUES ROUSSEAU (Le Contract Social e outros trabalhos de catequese política), votava a famosa DECLARAÇÃO DOS DIREITOS DO HOMEM E DO CIDADÃO. Vasado em linguagem enfática e declamatória, êsse transcendental documento muito serviu, de resto, ao individualismo da época. À Convenção Nacional, em 23 de junho de 1793, coube a tarefa de votar, novamente, a Declaração, inscrita, à guisa de preâmbulo, na Constituição Francesa de 24 de junho do mesmo ano. ( $\left.{ }^{*}\right)$

Aqueles dois notáveis acontecimentos, sob o aspecto positivo constitucional, referem todos os tratadistas, tiveram profunda influência, não só na Europa, como em todo o mundo, inclusive nas nascentes repúblicas americanas. Os chamados direitos fundamentais do homem e do cidadão passaram a compor, assim, em menor ou maior escala, as cartas constitucionais dos povos do universo.

Quanto ao plano internacional, são dignos de nota os seguintes documentos, relacionados com os direitos fundamentais da pessoa humana:

a) declaração da "National Catholic Welfare Conference", trabalho de equipe de 12 filósofos e juristas dos Estados Unidos, para a adoção de um projeto de Declaração dos Direitos Humanos;

(*) A atual Constituição francesa, promulgada em 27 de outubro de 1946, reafirmou, solenemente, em seu preâmbulo, os Direitos do Homem e do Cidadão proclamados em 1789: :Il réaffirme solennellement les Droits et Les Libertés de l'Homme et du Citoyen consacrés par la Déclaration des Droits de $\mathbf{1 7 8 9}$ et les principes fondamentaux reconnus par les lois de la République". 
b) ante-projeto aprovado pelas "Conversações Internacionais Católicas", de San Sebastian, em 14 de setembro de 1948;

c) projeto oferecido pela Comissão Jurídica Interamericana, em 1948, à consideração da IX Conferência Pan-Americana de Bogotá;

d) Carta da Organização dos Estados Americanos, assinada também em Bogotá, em 30 de abril de 1948, cujo artigo $5 .^{\circ}$ proclama os direitos fundamentais da pessoa humana sem fazer qualquer distinção de raça, nacionalidade, credo ou sexo;

e) Carta Internacional Americana de garantias sociais e Declaração Americana dos Direitos e Deveres do Homem, documentos assinados na aludida cidade de Bogotá; e, finalmente,

f) a Declaração Universal dos Direitos do Homem, aprovada, pela Assembléia Geral da Organização das Nações Unidas (ONU), a 6 de dezembro de 1948, como decorrência das finalidades dêsse organismo internacional, fixadas em sua carta adotada em São Francisco no dia 26 de junho de 1945.

No âmbito evolutivo do Direito Internacional, sempre tendente a proteger a pessoa do homem como ser moral, social e econômico, são ainda dignos de menção:

I) declaração dos direitos internacionais do homem, votada, em Nova York, pelo Instituto de Direito Internacional, a 12 de outubro de 1929 ;

II) esbôço de uma Declaração dos Direitos e Deveres Internacionais do Homem, elaborado pela Comissão Jurídica Interamericana sôbre problemas de guerra e paz, Comissão reünida, no México, entre 21 de fevereiro e 8 de março de 1945.

Poder-se-iam assinalar outras manifestações significativas de respeito à dignidade da pessoa humana, destacando-se, dentre elas, no terreno econômico, as reuniões de Dumbarton Oaks e de Bretton Woods. Visaram um melhor entendimento entre 
as nações e, em conseqüência, a fixação prática e efetiva daquele direito comum da humanidade, consoante a expressão lapidar de MANDELSTAN, na perene procura da sonhada paz mundial, com base no direito e na justiça.

0 registo dessa evolução não pode desconhecer a profunda e inelutável influência humanizadora dos novos direitos sociais, que superaram de muito os velhos direitos conquistados pelos movimentos individualistas do século XVIII. (**)

O saudoso presidente ROOSEVELT, em 1945, é oportuno salientar, resumiu magistralmente a expressão dessas novas liberdades, nos seus quatro princípios:

“1) Freedom of speech and expression everywhere in the world. 2) Freedom of every person to worship God his own way everywhere in the world. 3) Freedom of want which translated into world terms means economic understanding which will secure to every nation a healthy peace time life for its inhabitants everywhere in the world. 4) Freedom from fear which translated into world terms means a world-wvide reduction of armaments to such a pont and in such a thorougn fashion that no nation will be in a position to commit an act of physical agression against any neighbour anywhere".

A propósito, assim se exprime THEMíSTOCLES BRAN-

\section{DÃO CAVALCANTI:}

"Êstes quatro itens definem a direção tomada pelo mundo no sentido de ampliar o conceito da liberdade

(**) São dignos de menção, neste passo, os novos direitos humanos discriminados no art. 25 da Declaração Universal dos Direitos do Homem, aprovada e proclamada em Paris pela Assembléia Geral das Nações Unidas: "tôda pessoa tem direito a um nível de vida adequado que the assegure, bem como à família, a saúde e o bem-estar. e, em especial, a alimentação, o vestuário, a habitação, a assistência médica e os serviços sociais necessários; tem do mesmo modo direito aos seguros em caso de desemprêgo, enfermidade, invalidez, viuvez, velhice ou outros casos de perda de seus meios de subsistência por circunstâncias independentes de sua vontade". 
acima dos indivíduos, dos grupos, e mesmo das nações. A velha concepção individualista ampliou-se, embora conservando a essência de seu conteúdo. As garantias contra a violência individual ou dos grupos, as garantias contra a miséria e a pressão econômica, as garantias contra tôda a opressão que pretenda tirar a liberdade de pensamento em tôdas as suas manifestações, resumem as tendências modernas do direito, em seu estado atual de evolução. A moderna legislação do trabalho, as organizações de previdência e assistência social, o respeito e a atenção cada vez maiores pelas reivindicações sociais, exprimem bem o sentido da época em que vivemos". (Princípios Gerais de Direito Público, p. 130).

O Estado moderno e verdadeiramente democrático, na procura intensiva e extensiva do bem comum, sem repudiar, é certo, a essência de alguns dos grandes princípios de 1789, não mais se limita, hoje em dia, a compor o quadro de sua organização política dentro daquelas lindes estreitas do individualismo clássico, que proveio da revolução francesa e de outras fontes.

Ninguém melhor do que SEABRA FAGUNDES acentuou, entre nós, o evolver humanístico do direito público contemporâneo, no sentido de preservar, com medidas concretas e objetivas, as prerrogativas essenciais do homem como ser moral e social.

"Hodiernamente, as Constituições" - escreve o atual Ministro da Justiça do Brasil - "se têm desprendido da rígida concepção liberal do Estado, e, cedendo ao império de novas condições de vida, distendem o seu âmbito a todos os setores em que se faça precisa a ação equilibradora do poder público, no sentido de reger a vida coletiva, não sòmente no seu aspecto político, senão também no econômico, e até no moral. À regulação da forma de govêrno (organização e exercício dos poderes) e à declaração das chamadas liberdades públicas, que BLACK assinala- . 
va como as duas matérias essencialmente compreendidas no âmbito de uma Constituição (American Constitutional Law, ps. 2-3), se acrescenta a declaração dos direitos de fundo social, tão relevante, como a dos políticos. 0 vetusto sentido das primitivas "declarações de direitos", só tendo em vista o homem na ordem política, cede à conceituação nova dos direitos individuais em face do desequilíbrio na ordem econômica e social, que atinge tôda a estrutura jurídica do mundo moderno. Assim sendo, a estrutura do Estado vai sendo ( $\mathrm{sic}$ ) submetida a notáveis experiências, com o objetivo de torná-lo instrumento capaz de realizar, pràticamente, um trabalho positivo de equilíbrio, na ordem política pelo fortalecimento da autoridade e na ordem econômica pela proteção ao trabalho e subordinação do capital aos interêsses sociais". ( $O$ contrôle dos atos administrativos, $2 .^{a}$ ed., ps. 11-12).

A Constituição de WEIMAR, resultante da primeira hecatombe mundial (914-918), pode ser considerada, nesse sentido, como o ponto de partida das justas e incoercíveis conquistas sociais do homem trabalhador, já sàbiamente enunciadas nas encíclicas papais (Rerum Novarum, Leão XIII, 1891, e 1931), Quadragésimo Ano, por isso que inscreveu os $\mathrm{p}$ rimeiros preceitos de proteção e assistência ao trabalho livremente contratado e desenvolvido, não só em função dos atributos substanciais da pessoa humana, como em respeito à dignidade do próprio labor, "direitos em nome dos quais" - é o que evidencia JACQUES MARITAIN, apoiado em GUETZÉVIT$\mathrm{CH}$, - "o empregado se encontra perante o empregador em uma relação de justiça e como uma pessoa adulta, não como uma criança ou um servo. Existe, aqui, um dado essencial qjue ultrapassa de longe todo e qualquer problema de mera técnica econômica ou social, pois se trata de um dado moral, que afeta o homem nas suas profundezas espirituais". ( $\mathrm{O} \mathrm{Ho}$ mem e o Estado, 1952, editora AGIR, ps. 122-124). 
De WEIMAR até aos nossos dias a evolução tem-se acentuado, cada vez mais, extendendo-se paulatinamente à órbita internacional, na categoria de direitos supra-estatais, restritivos do conceito da soberania. "Colocar os direitos do homem e do cidadão sob a garantia do Direito Internacional, estabelecer a proteção internacional dos direitos do homem, eis o verdadeiro ideal humanitário que tende a fazer do homem um verdadeiro cidadão do mundo" - exclama o emérito GUETZÉVITCH. (As novas tendências do Direito Constitucional, S. Paulo, 1933, p. 179).

E o nosso LEVÍ CARNEIRO acrescenta:

“Na mesma ordem de idéias, LAPRADELLE, no projeto de Declaração dos Direitos e Deveres das Nações, apresentado, em 1921, ao Instituto de Direito Internacional, declarava que o objetivo social do Direito Internacional é a defesa dos direitos do homem: - Os Estados têm deveres em relação, não sòmente aos outros Estados, mas também em relação aos homens - como o de respeitar SUAS VIDAS, A SUA LIBERDADE, AS SUAS CRENÇAS". ( $O$ Direito Internacional e a Democracia - Rio, 1945, p. 37).

Por essa razão, conforme MARITAIN, a Carta Universal dos Direitos do Homem, proclamada pela ONU, depois de inscrever os direitos especiais em tôrno do trabalho e do trabalhador (além dos concernentes à proteção especialíssima da familia, como núcleo primário e fundamental da sociedade, bem como dos relativos à educação, à. cultura e à assistência), "inclui tanto os velhos como os novos direitos", não existindo, de modo algum, entre êles o antagonismo insuperável "que muitos escritores contemporâneos se comprazem em exagerar". (Op. cit., p. 124).

A Organização das Nações Unidas - "entidades política de máxima extensão na atualidade" - promove, dessarte, uma autêntica jurisdição internacional (Civitas Gentium Maxima), para o fim de serem atingidos os seus altos propósitos: "manter a 
paz e a segurança internacionais", "preservar as gerações vindouras do flagelo da guerra", "reafirmar a fé nos direitos fundamentais do homem" e "promover o progresso social e melhores condições de vida dentro de uma liberdade mais ampla". (Cartas das Nações Unidas - Nova York, 1948, Preâmbulo) (1).

CÉSAR BARROS HURTADO chega, mesmo, a pregar a doutrina da soberania política dos Estados, quer na vida interna das nações, quer na órbita internacional, fundada exclusivamente na soberania conatural do homem, "que es siempre el soberano". Explica o ensaista, dedicando suas palavras a MIRKINE GUETZÉVITCH :

"La soberanía es connatural y no política y la única soberanía connatural es la soberanía humana. Las outras, las llamadas soberanía nacional y soberanía internacional, son meras expresiones políticas de aquella soberanía.

"La soberanía humana es, pues, aquel poder supremo que tiene cada individuo por el solo hecho de nacer y que, aun cediéndolo para la convivencia social y política, no diluye su personalidad en el ente colectivo, ni menoscaba los derechos fundamentales que ella emanam.

"Pero la soberanía humana no es, por lo que a primera vista pareciera, ilimitada y absorbente, de tal modo que cada titular pueda ejercerla contra todos, discrecional y arbitrariamente.

(1) Veja-se, a propósito, a opulenta tese intitulada “ONU - ESTADO, PROTO-ESTADO ou SUPER-ESTADO?”, com a qual o Prof. JOSÉ NICOLAU DOS SANTOS se laureou catedrático de Teoria Geral do Estado na Faculdade de Direito da Universidade do Paraná, e publicada em Curitiba, no ano de 1952. Quanto à fisionomia política e jurídica da ONU, "estruturalmente considerada", - assentou o ilustre autor, numa de suas conclusões finais, - "é uma Confederação de Estados de caráter ecumênico (DELBEZ), isto é, uma ordem jurídica de máxima superposição" e que, "em relação ao MORE GEOMETRICO da História, constitui hoje um proto-Estado Federal, de extensão universal, marcando-se desde já em suas funções políticas e administrativas o desenvolvimento progressivo da "lei do desdobramento funcional" (SCELLE), típica do fenômeno federativo" (cf. conclusões V e VI, págs. 208-209). 
“La soberanía humana es limitada y su ejerció está condicionado al ejercicio de las soberanías connaturales de los demás. De ahí que el individuo para poder convivir se vea obligado a hacer delegación de faculdades en el conjunto, creando la soberanía política singular o general". (El Hombre Ante El Derecho Internacional, Buenos Aires, 1949, ps. 155-156).

5. Encontraremos em VICENTE RÁO precisos conceitos sôbre a absorção, nas sociedades, da filosofia da pessoa humana, para criar o direito:

“... sociedade e direito forçosamente se pressupõem, não podendo existir aquela sem êste, nem êste sem aquela. Ubi societas, ibi jus. Se a coexistência social resulta da natureza do homem, também da natureza do homem, que Deus fêz à sua semelhança, o direito decorre. Encontra-se, pois, a origem do direito na própria natureza do homem, havido como ser social. E é para proteger a personalidade dêste ser e disciplinar-lhe sua atividade, dentro do todo social de que faz parte, que o direito procura estabelecer, entre os homens, uma proporção tendente a criar e a manter harmonia na sociedade". ( $O$ Direito $e$ a Vida dos Direitos, p. 39, tomo I).

A pessoa humana, por isso mesmo, é o "direito vivo" (BOISTEL), dela provindo todos os caracteres de um direito qualquer.

A antiga jurisprudência romana, v.g., já declarava que o direito é constituido "hominum causa" (Digesto, 1,5), esclarecendo-nos GUIDO GONELLA que o homem "é não sòmente causa eficiente do Direito, mas, ainda, causa final. Ou seja, o Direito é do homem e para o homem". E mais:

“Através a recomposição do Direito comum e da filosofia ecolástica, o civilismo medieval repisou e insistiu neste princípio clássico e o transmitiu ao direito moderno. E concludente que na definição dantesca do Direito (considerado como "hominis ad ho- 
minem proportio") esteja sublinhada particularmente a natureza humanística do Direito, o qual é nela compreendido como uma relação proporcional entre sujeitos humanos; os próprios bens materiais, aos quais é atribuido o Direito, são bens dos indivíduos, ou seja, bens humanos. Não menos humanística inspiração tem a doutrina de VICO, o qual afirmou que o mundo do Direito é um mundo "fatto dagli uomini" (feito pelos homens); um mundo, portanto, da consciência e da vontade". (Bases de uma ordem social, p. 29).

Existe, portanto, na vida em sociedade, equacionada pelo direito,

"uma reciprocidade de poderes, ou faculdades, e de deveres, ou obrigações. Por êste modo, o limite do direito de cada um é o direito dos outros e todos êstes direitos são respeitados, por fôrça dos deveres, que lhes correspondem. É assim que o direito confere harmonia à vida e assim é que só com o direito dignamente se vive". (VICENTE RÁO, op. cit., p. 40).

Cabe acentuar, todavia, como o fêz, aliás, o catedrático paulista, que a consecução da coexistência social, com base na comunhão humana, não se apresenta como a única e suprema finalidade do direito. É que o direito, como fôrça viva do conglomerado humano, visa a

“obter, por meio da coexistência social harmônicamente organizada, o aperfeiçoamento da coletividade mediante o aperfeiçoamento do indivíduo". (Op. cit., p. 41).

O Código Civil Brasileiro regista a característica superior da personalidade do homem, como ser capaz de direitos e obrigações.

0 artigo $2 .^{\circ}$ daquele diploma, ao tratar das pessoas naturais, determina que "todo homem é capaz de direitos obrigações na ordem civil". 
É claro, por outro lado, que aquele expressão todo homem compreende os dois sexos da espécie humana: Pronunciatio sermonis in sexu masculino ad utrunque sexum porrigitur. (L. 195, D., de verb significatione, 50,16).

E mestre CLóVIS BEVILAQUA, dissertando, por sua vez, sôbre a noção de pessoa natural em face do nosso direito civil, assim expõe :

"Pessoa natural é o homem considerado como sujeito de direito e de obrigações. As idéias de homem e de pessoa natural não coincidem em tôda a sua extensão, por isso que pessoa natural é o homem numa determinada atitude na sociedade civil. A sociedade é o meio onde vive o homem; nesse meio, êle desenvolve a sua atividade em direções diversas, protegido sempre pela ordem jurídica e, portanto, podendo agir como pessoa; mas o homem pode ser encarado sob várias relações extranhas ou indiferentes ao direito. Não obstante, é certo que, perante o direito privado moderno, tendo desaparecido a instituição da escravidão, todo ser humano é pessoa. TEIXEIRA DE FREITAS propôs que, em vez da locução pessoas naturais, se usasse, para designar o homem, da expressão pessoa de existência visível, e o Código Civil Argentino, arts. 31 e 32, aceitou a inovação. A denominação pessoas naturais, diz o egrégio civilista (cf. "Esbôço", observações ao art. 17), dá a entender que não são naturais as outras pessoas; no entanto essas outras pessoas são igualmente naturais, porque são idéias personificadas, e a idéia, produto do espírito, é tão natural quanto o mesmo espírito, e êste por sua vez tão natural quanto o corpo. A expressão pessoa física desnatura o homem, continúa TEIXEIRA DE FREITAS, pois não é sòmente o corpo, não é sómente o animal que constitue o ente jurídico e sim o composto de alma e corpo. A de pessoa individuais é imprópria, porque há pessoas de existência ideal que não são coletivas. Parece-me, todavia, que a expres- 
são pessoa natural é bem expressiva, porque mostra, em primeiro lugar, o indivíduo movendo-se na vida jurídica, tal como a natureza o creou, ao passo que as outras pessoas já são combinações ulteriores, formações sociais, abstrações, e, em segundo lugar, alude à organização jurídica moderna, em que o indivíduo se destaca, nas relações de ordem privada, como elemento ativo da vida social". (Teoria Geral do Direito Civil, ps. 83-85).

O dispositivo do nosso Código Civil, segundo ainda argumenta CLóVIS, "tem um grande alcance", uma vez que representa, de resto,

"uma afirmação do valor jurídico dos sêres humanos, sem distinção de sexo nem de nacionalidade. A todos, de onde quer que venham, o Código faculta o ingresso na cidadela do direito, e oferece as seguranças da ordem jurídica. A escravidão e tôdas as instituições, que anulam a liberdade civil, são repelidas. Dentro do círculo, que a lei traça, para dirigir e harmonizar a atividade humana, o homem é livre e pode desenvolver as suas energias, adquirindo e conservando valores jurídicos". (Código Civil, v. I., p. 181).

Salientando, por seu turno, o "pensamento preliminar que está implícito em tôdas as doutrinas do jus naturae", ensina GIORGIO DEL VECCHIO:

"O direito corresponde a uma necessidade humana, e é inseparável da própria vida do homem. Ubi ho$m o, i b i$ jus. Onde quer que se esboce a vida humana, existirá, indefectìvelmente, ao menos em germe, uma ordem jurídica. Um juízo sôbre o justo e o injusto deve ser possível em qualquer caso de relação hominis ad hominem. A qualidade de sujeito de direito não depende, para o homem, de concessão extrínseca e arbitrária de quem quer que seja; essa qualidade deriva, imediatamente, do seu próprio ser, tanto que nem o próprio indivíduo tem o poder de aliená-la ou 
renunciá-la. Neste sentido, a lei, que atribue a cada um a qualidade jurídica de pessoa, ainda quando não sancionada pela ordem positiva, é uma lei natural. Ser, jurìdicamente, pessoa significa valer como tal diante dos outros. A juridicidade consiste, precisamente, nesta correlação entre vários sujeitos. Nenhuma afirmação de direito é possível sem a noção de um limite correspondente. Admitir que êsse limite possa ser fixado arbitràriamente iria de encontro ao princípio fundamental acima indicado, pois que implicaria a possibilidade de anular, pràticamente, o direito da pessoa". (Direito, Estado e Filosofia, p. 140).

Todo o mundo do direito, como se vê, nas suas mais variadas e multiformes manifestações, gira em tôrno do respeito à dignidade da pessoa humana.

Vale dizer: a pessoa é inviolável, cabendo-lhe, em conseqüência, direitos também invioláveis, que o sempre invocado RUY chamaria de direitos eternos, inauferiveis, essenciais ao desenvolvimento liberal do homem, os quais constituem, ao "derredor de cada um de nós, uma esfera sagrada, que à autoridade social não é lícito penetrar sem violência ou injustiça". Aduz o grande condor da nossa mentalidade jurídica e humanística, relativamente ao dever que incumbe ao Estado, como nação politicamente organizada, no tocante à proteção da dignidade da pessoa :

"Em relação às leis que presidem a êsse gênero de funções humanas, o Estado é apenas a grande proteção comum, a vigilância coletiva organizada e permanente. Aí o verdadeiro papel dêle é o de abstenção respeitosa perante o desenvolvimento regular dessas fôrças naturais e repressão igual contra as invasões recíprocas do domínio privado". (O Papa e o Concílio, p. 109).

6. O enunciado da tese enseja, também, uma afirmação primordial e atualizada do conceito realístico-escolástico de ARISTÓTELES, que "manteve com firmeza", no dizer de GO- 
NELLA, "o princípio da natural sociabilidade do homem e, por conseguinte, de sua natural tendência à sociedade em seus vários graus (da família à Comunidade dos Estados)".

Essa atualização do conceito formulado pelo sábio Estagirita, segundo a sua celebérrima passagem da POLíTICA $(O$ homem é por sua própria natureza um animal político destinado a viver em sociedade), vem mencionada por LÚCIO CRAVEIRO DA SILVA, no seu magistral trabalho "A Idade do Social", publicado sob os auspícios da Faculdade de Filosofia de Braga, nos seguintes têrmos:

"O homem, em Aristóteles, é um animal "político", o que em linguagem moderna devemos traduzir por animal "social". O homem precisa de sociedade, precisa de outros homens. $O$ industrial não pode explorar a sua indústria sem o auxílio de inúmeros cooperadores que lhe forneçam as máquinas e as matérias primas, os projetos técnicos e o trabalho dos operários. $O$ poeta e o literato não podem plasmar o ideal que os solicita sem a coadjuvação dos livreiros, dos encadernadores, dos fabricantes e fornecedores de papel e de tinta... O próprio eremita solitário ou a freira de clausura precisam de quem lhes forneça os hábitos de estamenha, as sandálias, a cadeira ou o banco e o leito humilde, os livros de devoção, e a luz para os ler, que sei eu? Ninguém pode viver e desenvolver-se humanamente sem pedir contìnuamente auxílio a um infindo número de colaboradores. $\mathrm{O}$ homem exige a colaboração, a sociedade. $O$ Robinson na ilha deserta ou o indivíduo isolado é uma abstração tão irreal como o átomo físico separado da molécula". (Op. cit., p. 17).

A sociabilidade humana é, como se vê, instintiva e natural, impelindo o homem a viver sempre em sociedade. Tal tendência não constitue, a rigor, privilégio do homem como ente livre e racional. Os representantes mais modestos da escala zoológica, se bem que interligados por meio de relações puramente de ordem material e sensível, vivem naturalmente em grupos; 
impulsionados à vida em comum pelas necessidades de nutrição, defesa e proteção dos mais fracos. S. TOMAZ, v.g., reconheceu êsse estado social, inerente a várias espécies animais, quando a êle se referiu sob a designação genérica de "animal gregale".

É óbvio que o exemplo deve valer apenas como demonstração da intensa e irremovível vida gregária que predomina nas sociedades, maximé na integrada pelo ser mais eminente, que é o homem. É que o animal não progride. Limita-se a viver pelos instintos materiais até o seu desaparecimento. $\mathrm{O}$ homem, ao contrário, desenvolve suas aptidões morais, intelectuais e físicas, sempre em contacto com os seus semelhantes, estimulado pela sua natureza racional e pelos ideais superiores que encontram ressonância na sua personalidade. Eis aí a grande característica do homem, que pode e deve melhorar a sua condição. "O animal" - o conceito é ainda de LÚCIO CRAVEIRO DA SILVA - "não progride. As abelhas descritas por Virgílio ou o cão de Tobias, que abanava a cauda jubiloso à chegada de seu dono, não diferem das abelhas das nossas colmeias e do cão de guarda das nossas quintas". (Op. cit., p. 15).

Mas, para que o homem (cuja vida isolada é, como já vimos, em regra geral, impossível) possa normalmente atingir os seus anseios de aperfeiçoamento moral, intelectual e físico, necessita da cooperação dos seus semelhantes. Uma vez esta realizada, chega, com o tempo, à conclusão de que ela The é benéfica. Passa, então, a desejá-la, a querê-la. Resulta que a necessidade da cooperação e a liberdade formam dois importantes elementos, que, conforme acentua OSWALDO ARANHA BANDEIRA DE MELO, com arrimo em farta e autorizada bibliografia estrangeira, "dão causa à vida social".

Decorre, inevitàvelmente, que o homem, no desenvolvimento de sua intensa vida gregária, ingressa espontâneamente em vários tipos de instituições ou de sociedades.

A sua coparticipação, nessas instituições ou sociedades, é procedida, em verdade, "simultânea ou sucessivamente, no mundo moderno, desde que nasce e durante tôda a existência", como assinala; com justeza, o prof. DARCY AZAMBUJA. 
As diversas instituições ou sociedades, a que o homem se vincula, são formadas por indivíduos ligados ou pelo parentesco, ou por interêsses materiais, ou por objetivos espirituais. Tôdas possuem, no entanto, uma finalidade em comum: a de assegurar ao homem, seu associado, "o desenvolvimento de suas aptidões físicas, morais e intelectuais e, para isso, lhe impõem certas normas, sancionadas pelo costume, a moral ou a lei". (AZAMBUJA, op. cit., p. 11).

0 primeiro grupo social, no qual o homem forçosamente ingressa, já se pode fàcilmente perceber, é a família, sociedade natural por excelência e composta de pessoas descendentes do mesmo antepassado comum, unidas pelo sangue e pelos laços da afeição, através do casamento. A família, assim grupada, "alimenta, protege e educa o homem", como célula social da mais alta importância.

Além da família, o homem, sempre impulsionado por seu instinto associativo, penetra em sociedades religiosas (igrejas), sociedades escolares (para fins educativos), sociedades universitárias (para a formação cultural de nível superior), tudo por sua vontade e no exercício das faculdades de sua personalidade livre e consciente. E, a par dos tipos associativos discriminados, o homem chega até a criar, êle mesmo, outras entidades, com fins econômicos, profissionais, ou simplesmente morais. Nascem, então, as emprêsas comerciais, os institutos científicos, os partidos políticos, os sindicatos, os clubes recreativos, as agremiações esportivas, etc., etc..

O homem, nessa imensa teia de ramificação de sua tendência social, vive e se eleva no seio da justaposição e interpenetração dos vários grupos humanos interligados. Daí a formação da sociedade prò̀riamente dita. Esta abarca, num sentido geral, "os grupos sociais de uma cidade, de um país ou de todos os países". E quando a extensão e compreensão do têrmo "sociedade" abrange todos os grupos sociais, de todos os países, teremos, nesse caso, como escreve AZAMBUJA, a sociedade humana, isto é, humanidade.

Não estaciona aí, contudo, o milagre de associação e coope- 
ração, para o mútuo e desejado auxílio, no sentido do aprimoramento de todos os comunitários, o qual só poderá ser atingido num clima de harmonia e paz jurídica e social, calcado essencialmente na justiça, que é a base da sociedade. 0 homem, mesmo antes do seu nascimento, a partir de sua concepção no ventre materno, já se acha integrado numa outra sociedade, que também tem o dever de assistí-lo, protegê-lo e fiscalizá-lo.

Qual será essa sociedade sui generis, prêsa estruturalmente à sua finalidade específica e diversa de tôdas as outras instituições ou sociedade, que acabámos de citar?

Trata-se, indubitàvelmente, da sociedade política, o Estado, centro polarizador de órgãos ou de funções administrativas, cujos objetivos primordiais e inconfundíveis são os de ordem $e$ defesa social. O Estado representa, assim, a forma política da sociabilidade (cf. STURZO, "Essai de Sociologie”, p. 61), em tôrno da qual, quer no seu conceito, quer no tocante às suas causas ou origens, divergem profundamente, é certo, os tratadistas de direito público, acirrando-se em pontos de vista antagônicos e não raro irreconciliáveis, consoante os sistemas filosóficos ou doutrinários, a que se filiam.

De qualquer maneira, porém, como esclarece AZAMBUJA, a nenhum indivíduo é dado furtar-se à influência dessa extraordinária organização:

"Com exceção da família, a que, pelo nascimento, o homem forçosamente pertence, mas de cuja tutela se liberta com a maioridade, em tôdas as outras sociedades êle ingressa e delas se retira quando quer, sem que ninguém possa obrigá-lo a permanecer. Da tutela do Estado, o homem não se emancipa jamais. 0 Estado o envolve na teia de laços inflexíveis, que começam antes de seu nascimento, com a proteção dos direitos do nascituro, e se prolongam até depois da morte, na execução de suas últimas vontades". (Op. cit., p. 12). 
O Estado tem, portanto, poder de mando, quer perante os indivíduos, quer perante a sociedade, no desempenho do Govêrno, ou seja, no exercício da autoridade, que é o Estado em movimentos ativos de execução de tarefas administrativas. Edita, por isso, normas que, sendo justas, necessárias, ou convenientes à sua suprema finalidade, que é o bem comum, se apresentam com o caráter geral e coativo, dentro do território em que exerce a sua soberania, a todos obrigando como sujeitos ativos ou passivos de direitos e obrigações.

7. Surge-nos, então, como corolário lógico de tôda a contextura das vidas humanas que participam da sociedade e militam na esfera do Govêrno, que dimana da organização estatal, o problema, tantas vêzes discutido, mas nem sempre compreendido nos seus justos limites, da aparente antimonia entre a liberdade da pessoa humana e a fôrça operante ou executiva da autoridade.

Diga-se, desde logo, que o Estado moderno, para fazer jus a essa denominação, sem desdoiro para os foros de aprimoramento social e cultural da civilização contemporânea, deve existir para servir ao homem, e não êste para serví-lo.

O Estado, quer seja monárquico, quer seja republicano, haverá de ser, em si mesmo, nunca um fim, mas sempre um meio altamente ético e realizador, para que a pessoa humana consiga os seus fins. São de ATALIBA NOGUEIRA êstes conceitos oportunos e esclarecedores:

"É por isto que afirmamos que o indivíduo não foi feito para o Estado, mas sim o Estado para o indivíduo, para o seu bem estar moral e material, para a sua felicidade. Nesta doutrina, não existe o Estado que cria o Direito, mas o Estado que o descobre, reconhece, determina, aplica, sanciona, pondo a seu serviço a coação física. A fonte mais profunda do direito não é a vontade do Estado, mas a exigência da razão, a consciência moral e jurídica da humanidade, o reflexo da imagem divina impresso na alma hu- 
mana, aquela projeção da lei eterna, donde se origina aquele código natural, anterior e superior a todos os códigos. O direito não nasce com o Estado, mas com o homem. Escrito ou consuetudinário, não deixou nunca de acompanhar o homem. Existe para servir o homem, como também para servir o homem existe o Estado". (O Estado é meio e não fim, 2. ${ }^{\mathrm{a}}$ ed., p. 153).

O fim do Estado é a conquista para o homem - não sob o prisma do liberalismo individualista, que subordina a sociedade ao uso egoístico do indivíduo, sem atenção aos supremos interêsses coletivos - de uma vida melhor, fundada no seu aperfeiçoamento físico, moral e intelectual.

Mas, para que o Estado possa atingir os seus fins, em benefício dos indivíduos e da sociedade em geral, cabe-lhe a privatividade da ação governamental, que se exerce e desenvolve através de vários orgãos, cada qual agindo dentro de sua esfera própria de atribuições, cada qual dinamizando, por assim dizer, a sua competência de funções. Essa autoridade governativa, inerente à exteriorização dos atos de comando social e político, é essencial à ordem pública, como resultante do fenômeno, já descrito, da sociabilidade. E esta ordem, segundo PEDRO CALMON,

“é igual à autoridade. 0 contrário da ordem é a negação da autoridade. $\mathrm{O}$ princípio autoritário permite a coordenação social, ou seja, a Nação. Assegura a estabilidade pacífica da população no seu território e se substitue à anarquia dos sentimentos individuais : govêrno, então, é o próprio Estado. Não há tribus selvagens, sociedade primitiva, corporações humanas, sem um comando". (Curso de Teoria Geral do Estado, 3. ${ }^{\text {a }}$ ed., p. 174).

8. A autoridade, todavia, deve manter-se em sua justa medida. Ela deve ser, como define RAMELLA,

"ni débil ni excesiva. Cualidad la más difícil de en- 
contrar en la historia de los gobiernos. Si las ideas tienen una influencia decisiva en la vida de los pueblos y en el proceder de los gobernantes, se ha de insistir denodadamente en precisar bien los límites de la autoridad y no conformarse con aquella comprobación, pues callar por estimar que la palabra se perderá en el vacío sería tanto como suponer que el hombre ha renunciado definitivamente a obrar conforme a la razón. Por lo mismo que se asiste a una crisis de la autoridad, como lo han denunciado notables autores, conviene levantar en altos los valores inmutables, por si algún caudillo, de esos que en la historia suelen ser alma y nervio de una causa, los tomara como bandera de combate y triunfara con ellos sobre la anarquía y sobre la fuerza física".

(La Estructura del Estado, p. 71).

A autoridade, nessas condições, deve ser posta ao serviço das liberdades da pessoa humana, sem prejuízo para os superiores e legítimos interêsses da coletividade. Isto é: a autoridade tem a marcá-la, nìtidamente, na era em que vivemos, o seu cunho social, jamais devendo descambar para a dominação injusta, ou para o abuso de poder. A autoridade, por outras palavras, deve ser profunda e racionalmente limitada, baseados os seus poderes nos princípios de justiça social e distributiva; bem como nos direitos fundamentais da pessoa humana. Ela não deve ser, em suma, nem hipertrofiada (excesso de autoridade), nem atrofiada (deficiência ou falta de autoridade).

Eis os dois grandes extremos da crise de autoridade, crise que freqüentemente ocorre no mundo moderno: "Ora predomina a absoluta liberdade, ora a absoluta autoridade", como observa RAMELLA, citando TRISTÃO DE ATAIDE. (Op. cit., p. 72).

Nada de mística da autoridade, nem de mística da liberdade, mas, antes, e acima de todos e de tudo, o "equilíbrio entre a liberdade e a autoridade", de conformidade com o que pontifica SAMPAIO DÓRIA: 
"Cada uma tem sua esféra própria de ação. Sôbre não se chocarem, uma é condição da outra. Os indivíduos são livres por direito próprio, e seu poder de ação só tem por limites igual poder dos outros, expresso na lei, que êles mesmos tenham votado. A autoridade não é milagre que venha do céu, ou poder que se identifique na vontade de um homem. Mas um poder que emana da coletividade, para lhe assegurar as condições de vida e desenvolvimento. É uma coação incontrastável, não para sacrificar a liberdade, mas para defendê-la em seu exercício. Coexistem em harmonia, liberdade e autoridade, o indivíduo e o Estado. Aquêle, com um destino próprio, um fim em si mesmo; e êste, meio para a realização do destino humano". (Curso de Direito Constitucional, primeiro tomo, p. 33).

Autoridade e liberdade, no bom sentido, não são, portanto, duas noções antinômicas, duas realidades inimigas. A primeira não é mando absoluto e despótico; e a segunda, por sua vez, também, não é a faculdade de o homem poder fazer o que bem entenda. Ambas, indiscutivelmente, encontram seus limites nas exigências do bem comum.

E qual o instrumento apto à consecução do justo equilíbrio entre a liberdade e a autoridade?

Sem dúvida que o ordenamento jurídico, fundado na moral e destinado a precatar os ideais de justiça!

ALCEU AMOROSO LIMA observa, comentando a doutrina dos documentos pontifícios:

"Antes de tudo, restauração da primazia do Direito. O Direito é a medida da ordem social. Não é esta que é a medida daquele. Êsse ordenamento jurídico não tem por função dominar, senão servir, tender para desenvolver e aumentar a vitalidade da sociedade na rica multiplicidade dos seus fins, conduzindo até à sua perfeição tôdas e cada uma das energias em 
pacífica cooperação e defendendo-as, com meios apropriados e honestos, contra tudo que entorpeça o seu pleno desenvolvimento. Essa segunda sentença volta a afirmar a autonomia do Direito, contra a concepção instrumental do Direito a serviço do poder que o maneja. O Direito é fonte, é medida, é norma por si mesmo. Sua função, porém, não é servir de instrumento de domínio, mas, ao contrário, concorrer para que cada uma das energias sociais se manifeste em sua vitalidade própria". (Mensagem de Roma, p. 136).

A ordem jurídica, consagrada pelo Estado, é fôrça que impõe limites aos seus próprios órgãos.

O Estado, limitando-se a si mesmo, não só para o efeito de racional divisão dos seus múltiplos e complexos encargos administrativos, como também para assegurar e limitar as liberdades individuais, configura hodiernamente o Estado de Direito, eminentemente responsável e atuante. A função do Estado, nesse sentido, visando à proteção dos direitos fundamentais da pessoa humana, caracteriza-se por um autêntico custos justi, na lição de JONATHAS SERRANO. Êste adverte, porém, não ser essa - a tutela dos direitos - o fim único da organização estatal,

"porque seu organismo, seu modo de agir, sua constituição se revestem de formas jurídicas. Mas, ao lado dessa função primária de tutela jurídica, existe outra, importantíssima: de assistência, destinada a auxiliar os interêsses gerais e a facilitar o aperfeiçoamento material, intelectual e moral, tríplice aspecto da civilização". (Op. cit., p. 64).

O Estado, nessas condições, deve sempre aparecer e atuar, na qualidade de legítima e serena sentinela do Direito, para a execução dos seus elevados fins.

9. O instrumento positivo da ordem jurídica reside, em primeiro lugar, na Constituição, lei fundamental adotada pelo 
Estado e por meio da qual se rege e de que procedem tôdas as leis por êle editadas.

Mas, aqui ressuma uma verdade jusnaturalística incontestável: a pessoa humana possue liberdades fundamentais, que especificam uma solene anterioridade dos direitos naturais e inalienáveis do homem, não decorrentes, como já se demonstrou, das normas positivas ou jurídicas consagradas pelo Estado. Essas liberdades fundamentais preexistem ao nascimento do próprio Estado. Êste apenas lhes dá contornos pelo seu ordenamento sócio-jurídico, desde que a lei delas cuida, inclusive a Lei das Leis, que é a Constituição, tão só para proclamá-las e resguardá-las, não apenas quanto às relações de homem para homem, como perante o próprio Estado. Tais contornos normativos funcionam, então, como freios e contrapesos, destinados a limitar a esfera de ação do poder público, ou melhor, da vontade dos agentes físicos, que são os titulares dos órgãos constituidos para a execução das funções da entidade estatal.

Daí o dizer ROMANOSI, através de escorreita definição, que a Constituição de cada Estado, como nação polìticamente organizada, vem a ser "a lei que o povo impõe aos que o governam para garantir-se contra o despotismo dêles".

O nosso CARLOS MAXIMILIANO arrola, de sua vez, as mais correntias definições do supremo estatuto, que condensa, na acepção geral, a própria organização do Estado, contendo o substratum das instituições políticas, jurídicas, sociais e econômicas que o formam e lhe caracterizam a organicidade.

Já ARISTóTELES, em sua celebrada POLfTICA, definira a Constituição como sendo o "princípio segundo o qual estão organizadas as autoridades públicas, especialmente aquela que é superior a tôdas e soberana". O grande filósofo, entretanto, como explica DARCY AZAMBUJA, "referia-se sòmente ao poder e esquecia os governantes". (Op. cit., p. 172-173).

A Constituição, por outro lado, nos Estados legìtimamente democráticos, não se queda insensível às liberdades fundamentais, proclamando-as como autênticas conquistas do homem e da civilização. 
O sentido jurídico do poder constituinte de cada Estado é que traça os limites para o exercício da autoridade-governativa pelo Estado e para o gôzo das liberdades essenciais pelos cidadãos, estruturando as suas normas constitucionais na moral, no direito e na justiça.

Aparecem, dessa maneira, as expressões encontradiças no linguajar dos tratadistas e que se equivalem no entendimento comum dos cidadãos: direitos individuais, liberdades públicas, direitos do homem e do cidadão; todo um conjunto, enfim, de condições mínimas para que a pessoa humana possa, em regime de segurança e bem-estar, conseguir o seu aperfeiçoamento. Elas também são conhecidas sob a denominação de "obrigações negativas" do Estado. Constituem, sob êsse aspecto, o non facere imposto a tôdas as manifestações do aparelhamento estatal, no sentido de fixar a zona de ação humana dentro da qual o Estado, por seus órgãos, ou por seus agentes funcionais categorizados e providos de qualquer parcela de autoridade, sòmente pode atuar para assistir as liberdades fundamentais do indivíduo, e nunca para coartá-las ou ofendê-las, a menos que se cogite de mau uso das mesmas, com prejuízo para a ordem pública.

Podemos dizer que êsse campus de ambiência inalienável e sagradas do homem tem os seus lindes demarcados, tradicionalmente, por aqueles direitos humanos e essenciais, concernentes à vida; à propreiedade (como direito pessoal, mas de uso condicionado ao bem-estar social) ; à expressão do pensamento; à locomoção; à inviolabilidade do lar; à liberdade de culto (desde que a sua prática não ofenda a moral) ; à liberdade de reunião $e$ de associação (para qualquer fim lícito e justo, não desaconselhado pela ordem pública); à sua manifestação, por escrito ou oralmente, perante quaisquer autoridades (direito de petição) ; à liberdade espiritual (que compreende a liberdade de consciência e a liberdade de pensamento, sendo dela corolários a liberdade de cátedra e a liberdade de imprensa); à liberdade e segurança do trabalho ( com a sua atual concepção de que, além de direito, constitui também um dever social) ; à igualdade 
jurídica de todos perante a lei; à liberdade política (direito de sufrágio, podendo votar e ser votado, e bem assim ocupar cargos públicos, de acôrdo com a capacidade de cada um e as exigências legais), etc., etc..

O conjunto dêsses direitos fundamentais, em suma, se desdobra, segundo os tratadistas, dentro da classificação tripartida: a) igualdade civil; b) liberdade civil; e c) liberdade politica (2). Mas, desde que inscritos tais direitos em uma Constituição, passam êles a figurar como direitos fundamentais do homem (apud PONTES DE MIRANDA, "Comentários à Constituição de 1946", vol. III, pág. 145), sejam ou não supraestatais, pois que as Constituições "fazem fundamental o que não não é (ou ainda não é) supraestatal". Por fôrça, é óbvio, do princípio da supremacia da norma constitucional, nos Estados de Direito.

O conteúdo dos direitos individuais, assim considerados porque imanentes à natureza do homem e anteriores, como já ficou dito, ao Estado, está latente em tôdas as constituições

(2) JELLINEK ensina que a personalidade dos cidadãos deve ser reconhecida, no campo do direito público, através de quatro status, "entendendo-se esta palavra num sentido mais amplo do que o técnico, isto é, como um complexo de direitos e de obrigações", segundo refere GROPPALI em sua "Doutrina do Estado" a tratar das classificações sistemáticas dos direitos públicos subjetivos. Os cidadãos assumem, assim, quatro posições distintas, duas passivas e ativas as outras duas. Ei-las: a) o status subjectionis, "compreendendo os direitos de supremacia que o Estado exerce sôbre os cidadãos e aos quais corresponde o dever de obediência, de fidelidade de prestações pessoais e reais, por parte dêstes; b) o status libertatis, compreendendo os direitos de liberdade constituídos pelo poder jurídico por parte dos cidadãos de dispor da sua pessoa e suas coisas, como também de agir de acôrdo com sua própria vontade nas zonas de atividade não vedadas e indiferentes ao direito; c) o status civitatis, compreendendo os direitos cívicos que os cidadãos têm contra o Estado para obter a proteção jurídica no interior e no exterior, a prestação de serviços públicos, o ingresso em cargos civís e militares quando satisfaçam determinadas condições; e d) status activae civitatis, compreendendo os direitos políticos atribuídos aos cidadãos de partecipar na vida do Estado (eleitorado ativo e passivo)" - op. cit., ed. Saraiva, págs. 247-248. 
americanas, que, nesse particular, se abeberaram nas conquistas do cidadão, em relação ao Estado, proclamadas pela Revolução Francesa de 1789.

10. A liberdade, como já se mencionou e nunca é demais repetir, constitui um dos atributos essenciais da personalidade humana, como elemento natural e necessário na sociedade. A liberdade, todavia, também se apresenta como atributo jurídico, porque limitada pelo Direito. O Estado, na consecução dos seus fins, que visam à efetivação do bem comum (a conquista, para os homens, de sua felicidade na terra - ef. CATHREIN, Filosofia Morale, v. II, p. 563), o Estado, como dizíamos, é o guardião do Direito, cabendo-lhe, de consegüinte, regular o uso dêsse jus fundamental correspondente a todo homem, sem quaisquer distinções de raça, nacionalidade, crença, condição econômica ou estado social.

Vejamos, por isso mesmo, e um pouco mais a fundo, a verdadeira conceituação de liberdade.

Definiu-a, concisamente, a declaração Francesa de 1789: "A liberdade consiste em poder fazer tudo que não prejudique a outrem: assim, o exercício dos direitos naturais do homem não tem outros limites senão os que asseguram aos demais membros da sociedade o gôzo dos mesmos direitos. Êsses limites sòmente a lei poderá determinar. - A lei não pode proibir senão as ações nocivas à sociedade. Tudo que não é proibido por lei não pode ser impedido, e ninguém será obrigado a fazer aquilo que a lei não determinar".

É verdade que essa definição já se acha superada no tempo e no espaço, pois contém várias falhas (cf. A. de SAMPAIO DóRIA, op. cit., p. 37). Mas, segundo imparcialmente refere DARCY AZAMBUJA,

"o seu valor é inegável e tudo que nos Estados modernos se realizou depois pelo livre exercício da atividade física, moral e intelectual do homem, nela en- 
contra o fundamento histórico e se inspira em seus generosos princípios. Pode-se discordar da base filosófica em que ela se apóia, não se poderá negar a grandeza e a verdade dos fins que ela visou". (Op. cit., ps. 160-161).

A liberdade, hoje, antes de ser uma afirmação do individualismo, que caracterizou o período decorrente da revolução francesa, tem, repetimos, um conteúdo nìtidamente social, cuja origem, como já foi dito, está plantada espiritualmente no homem. Êste deve ser apreciado sob duplo aspecto: "o homem é tanto pessoal como social; é uma pessoa e um cidadão" - como doutrina FULTON J. SHEEN, no seu admirável "O Problema da Liberdade", p. 126, ao cuidar da liberdade em face do Estado. $O$ filósofo americano, criticando os desvirtuamentos nocivos da liberdade, processados sob a inspiração dos mitos do coletivismo e do individualismo, ambos falsos e inaceitáveis, esclarece que

"a liberdade nasceu do reconhecimento dos direitos da pessoa e floresce no reconhecimento das responsabilidades sociais. Direitos e deveres são correlativos, e assim não pode haver um pires com lado côncavo, nem um quadro sem os quatro lados, do mesmo modo não há direitos sem deveres". (Op. cit., p. 126).

$\mathrm{E}$ adita o notável pensador, concordante, magistralmente, com a concepção cristã de liberdade:

“Essse conceito de liberdade é também falso, porquanto coloca a liberdade na coletividade e não no homem, e identifica a liberdade com aquilo que os homens fazem e não com aquilo que o homem é. Torna-se então a liberdade um atributo do Estado e não do homem; nessa teoria o composto é que é livre, não os componentes. Cada pessoa é como a engrenagem de uma máquina, cuja função é inteiramente determinada pelo maquinista do Estado ou pelo ditador. Dois erros devem então ser evitados: um que esque- 
ce a finalidade da liberdade, e outro que pretende que a liberdade reside apenas na coletividade, e não no homem. Se evitarmos essas duas posições extremas, a de um liberalismo moribundo e a de uma crescente ditadura, chegaremos à mais positiva e exata idéia de liberdade, a que evita os dois erros acima apontatados: a liberdade não é o direito de fazer o que me pareça, nem é a necessidade de fazer o que quer que o ditador me imponha: ao contrário, a liberdade é o direito de fazer o que eu devo. Nessas três expressões "querer", "ser necessàriamente" e "dever" estão contidas as três opções que se oferecem ao mundo moderno. Das três escolhemos "dever". Essa pequena palavra "dever" significa que o homem é livre. $\mathrm{O}$ fogo é necessàriamente quente, o gêlo é necessàriamente frio, mas o homem deve ser bom. "Dever" implica moralidade, isto é, um poder moral distinto do poder físico. A liberdade não é o poder de fazer qualquer coisa que se queira, tão freqüentemente enunciado pelo moço moderno nestas palavras: "Posso fazer isso, se quiser, não posso? Quem me impedirá?" Certamente você pode fazer qualquer coisa que lhe agrade ou queira. Pode roubar o seu vizinho, pode bater na sua mulher, pode encher colchões com giletes usadas, e também matar a tiros de metralhadoras as galinhas do vizinho, mas você não deve fazer nada disso porque dever implica moralidade, direitos e obrigações". (Op. cit., ps. 29-30).

Liberdade não é, portanto, poder ilimitado. Antes, pelo contrário, consoante pondera SAMPAIO DóRIA, "liberdade é poder limitado de ação. Limitado pelo direito, que a lei sancione. $\mathrm{E}$ onde é obedecida a lei, que consagra o direito, a ordem jurídica está consolidada, e vigilante a defesa da pátria. Sòmente onde a liberdade fôsse mais do que atividade compatível com a coexistência de todos, isto é, onde a liberdade 
fôsse substituida pelo arbítrio dos indivíduos, só aí a ordem periclitaria, e correria a pátria perigo comum". (Op. cit., ps. 43-44).

É de GUIDO GONELLA a afirmativa segundo a qual

"a liberdade tem em si mesma o seu limite: ninguém se deve servir da liberdade própria para violar a dos demais. Se a liberdade não fôr garantida por um poder capaz de impedir ao indivíduo de ultrapassar os limites do lícito e permitido, ter-se-ia, não a ordem, mas a desordem social, à qual assim se refere MONTESQUIEU, tratando do domínio dos decênviros: "Em Roma não existiam senão duas espécies de homens: aqueles que gemiam na escravidão e aqueles que, por egoísticos interêsses particulares, a impunham aos outros". (Op. cit., p. 217).

Profundamente influenciado pela definição de liberdade constante de nossa primeira carta constitucional e, ainda, pela lição de STUART MILL (cap. $10^{\circ}$ de sua "Liberdade"), SAMPAIO DóRIA define a liberdade, como fenômeno social e jurídico, nestes têrmos:

"Consiste a liberdade em fazer, ou deixar de fazer. tudo que, praticado ou deixado de praticar por todos, não desagregue a sociedade, nem lhe impeça o desenvolvimento". (Op. cit., p. 43).

LEóN DUGUIT, em seu "Traité de Droit Constitutionel", ministra a seguinte definição de liberdade:

“É o poder que pertence a todo indivíduo de exercer e desenvolver sua atividade física, intelectual e moral, sem que o Estado lhe possa determinar outras restrições, senão as necessárias para proteger a liberdade de todos" (v. III, p. 594).

Bem se vê, por aí, que a liberdade, quando desviada do seu natural e necessário limite moral e jurídico, não será mais liberdade, mas, sim, licenciosidade, arbítrio, autêntico abuso que 
deve ser coibido pelo Estado, através dos seus órgãos de comando social e administrativo, no exercício legítimo de sua missão tutelar de guarda inflexível da ordem e da segurança social.

Exaltando a liberdade, PINTO FERREIRA sustenta que "o direito de liberdade é um princípio sagrado, que serve de fundamento a tôda a ordem social. Sem liberdade não há justiça, sem justiça não há progresso, e sòmente com a liberdade, como uma auto-determinação da personalidade, diante das condições históricas do meio social, pode o homem atender à urgente exigência de sua elevação espiritual na vida" (op. cit., p. 471).

- LASKI define a "liberdade como a afirmação por um indivíduo ou grupo de sua própria essência", sendo que HAURIOU, no seu liberalismo filosófico, diz que a "essência" da liberdade política consiste na participação dos cidadãos no govêrno. ( $L i$ berty, 1935, IV, p. 444).

Só os regimes tirânicos ou despóticos suprimem a verdadeira liberdade. Esta, dentro dos seus justos e necessários limites, é o oxigênio que alimenta as generosas e duradouras creações do gênio humano, dando-lhes vitalidade compativel com a dignidade da pessoa.

Urge, porém, que em seu nome (que, no dizer de RUY, "tantos trazem na bôca, sem sentirem no coração") sejam tão sòmente votadas e aplicadas, com sinceridade e patriotismo, leis justas e de conteúdo humanístico-jurídico, realmente convenientes ao aprimoramento dêste grande trinômio Homem-Sociedade-Estado, na marcha da civilização em busca da "felicidade de todos para que cada um seja feliz", na bela síntese de PONTES DE MIRANDA.

As leis injustas, iníquas ou monstruosas, desconhecendo os direitos e deveres recíprocos do homem, da sociedade e do Estado, criam a desordem e, de conseqüência, realizam a injustiça, 
ocasionando, sem dúvida, o crepúsculo daquela proporção, daquela igualdade, daquela harmonia nas relações "hominis ad hominem", que constitui, essencialmente, a justiça.

11. A todo direito corresponde u'a ação para protegê-lo, para torná-lo efetivo quando necessário, para dinamizá-lo, enfim, como centro operante de equilíbrio entre as variadíssimas relações ou entrechoques de interêsses que surgem na comunidade social. Assim ocorre no ramo do direito privado (art. 75 do Cód. Civil Brasileiro).

A tôda liberdade fundamental, como atributo da personalidade humana, cabe, por igual, uma garantia jurídica específica, de natureza eminentemente pública, sem a qual, muitas vêzes, o próprio direito subjetivo poderia perecer ou estar destinado a ficar inscrito nas cartas políticas como simples declaraçóes formais, sem alma e sem matiz, "como sonados pensamientos, pero jamás como derechos", segundo a elegante expressão de CARLOS S. FAYT. (Los Derechos Del Hombre y sus Garantias Constitucionales, Buenos Aires, 1945, p. 140).

Sem dúvida, as declarações de direito, ainda que consagradas nas leis maiores, mas desprovidas do arriete protetor de suas garantias, estariam fadadas a ser relegadas a plano

"de vanas enunciaciones, de líricas postulaciones. Serían a lo suma un punado de palabras gloriosas, que no pudiendo hacer valer su significación y contenido, tendrían el valor de una mansa y callada idea, grávida de exaltaciones, transformada en hueca y vacía por su imposibilidad de realizarse". (FAYT, op. cit., p. 140).

Daí a absoluta necessidade da existência, nas cartas constitucionais, a par das solenes declarações de direitos públicos subjetivos, ou juntamente com elas, de um amplo e generoso sistema de institutos jurídicos, capaz e armado de meios objetivos e concretos para resguardar a inteireza e a plenitude do exercício das liberdades individuais. 
Tal sistema de proteção política e jurisdicional dos direitos fundamentais do homem, como já se enunciou, tem a denominação de garantias dos direitos individuais, ou seja, das liberdades fundamentais da pessoa humana diante do Estado.

Existe, ademais, uma nítida diferenciação, segundo as normas jurídicas do moderno Estado de Direito, entre as declarações pròpriamente ditas e suas garantias constitucionais.

"Devem-se separar, no texto da lei fundamental", - como esclarece procedentemente PINTO FERREIRA, arrimado nos conceitos de RUY BARBO$\mathrm{SA}$, - "as disposições meramente declaratórias, que são as que imprimem existência legal aos direitos reconhecidos, e as disposições assecuratórias, que são as que, em defesa dos direitos, limitam o poder. Aquelas instituem os direitos; estas, as garantias; ocorrendo, não raro, juntar-se, na mesma disposição constitucional, ou legal, a fixação da garantia, com a declaração do direito". (Op. cit., v. 2, p. 506).

12. Não se deve olvidar, por outro lado, que recentes indagações, procedidas no campo do direito político, estabeleceram uma discriminação dos direitos fundamentais em absolutos e relativos. Os relativos variam, no tempo e no espaço, segundo o gráu de liberdade do indivíduo em face do Estado, "com uma relativa mudança da técnica das declarações". (PINTO FERREIRA, op. cit., p. 505).

Os direitos absolutos se encontram, todavia, "de frente ao Estado” (THOMA, apud PINTO FERREIRA, op. cit., p. 148), constituindo, dessa maneira, liberdades fundamentais imunes a qualquer forma de arbítrio ou intervenção por parte do Poder Público, porquanto valem por si mesmas, independentemente da regra constitucional ou legal. São, em suma, os "direitos supra estatais", a que se refere PONTES DE MIRANDA. Esses direitos fundamentais, inalienáveis e imprescritíveis, representam o ponto de partida para a busca de uma solução equilibra- 
da da eterna equação the man versus the State, repositório, mesmo, de afirmações as mais solenes e universais em tôrno da dignidade da pessoa humana, como ente moral e social, e dos regimes de liberdade.

Como expressões típicas de direitos fundamentais absolutos, dão-nos os tratadistas os exemplos concernentes à proteção da vida, à proteção da liberdade pessoal, à proteção da inviolabilidade do domicílio e da correspondência (correios, telégrafos, telefones).

Seriam relativos, no entanto, de acôrdo com a opinião de PINTO FERREIRA, os direitos de contrato, de propriedade, de comércio e indústria,

"valendo conforme a lei (nach Massgabe des Geset$z e s$ ), ou nos limites da lei (innerhalb der Schranken), como se vulgarizou na técnica da constituição de Weimar, seguida constantemente, nesse aspecto, pelo constitucionalismo nacional". (Op. cit., ps. 505506). Do mesmo teôr a lição de PONTES DE MIRANDA (Coms. à Const. Bras. de 1946, v. III, p. 146).

13. Na ordem jurídica, predominante nos Estados de Direito, ninguém poderá desconhecer a supremacia das normas constitucionais, sejam elas de natureza consuetudinária (como na Inglaterra, onde a magistratura acata, zelosamente, os princípios seculares da Common Law), sejam de natureza escrita (como em tôdas as repúblicas americanas).

Essa supremacia traduz, já de si, uma das importantes garantias das liberdades fundamentais da pessoa humana em face do Estado. Pois que tôdas as constituições modernas consagram, cada qual a seu modo e no estilo do regime adotado, as declarações de direitos individuais (públicos subjetivos) (3).

(3) A "Declaração dos Direitos do Homem e do Cidadão", enfàticamente pronunciada pelos constituintes franceses em 1789, já continha o princípio doutrinário segundo o qual "tôda sociedade em que não esteja assegurada a garantia dos direitos nem estabelecida a separação dos poderes não tem constituição" (art. 16). 
As normas constitucionais, por sua manifesta fôrça limitativa do poder, correspondem, no fundo, como que a um dique destinado a conter a preamar do arbítrio daqueles que, acastelados no zimbório do mando e adeptos corruptos (e corruptores) das legendas maquiavélicas, justificando os meios com os fins, investem contra as mais legítimas imunidades da pessoa.

Daí decorre o imperativo da superlegalidade constitucional, técnica jurídica que visa a proteger o homem, sem distinção de raça, nacionalidade ou religião, não só contra o arbítrio absorvente do executivo, mas, também, contra os possíveis excessos da onipotência parlamentar, resguardando, dessa forma, a intangibilidade da constituição, para aquele nobre e generoso intento.

É expressiva, nesse sentido, a lição de MIRKINE GUETZÉVITCH, quando apregôa e justifica a jurisdição constitucional como ponto alto no mecanismo do processo da racionalização do poder. Escreve o emérito constitucionalista:

"La cuestión del control jurisdiccional sobre la constitucionalidad de las leyes ha sido ampliamente estudiada. La misma idea del Poder constituyente, la idea de la supremacia de la Constitución, conduce a la superlegalidad constitucional (Confr. HAURIOU - Précis de Droit Constitucionnel, Paris, 1923, p. 276) de las leyes constitucionales con relación a la legislación ordinaria (La definición más afortunada e más democratica de este problema ha sido dada por L. LUGUIT, que estabelece la jerarquia de las leyes siguientes: "en la cima, la ley suprema, superior a todas las otras, la Declaratión de los derechos. Más abajo, las leyes constitucionales rígidas que le son subordinadas, pero que son superiores a las leyes ordinarias. Y, por fin, estas últimas que no pueden contener ninguna disposición contraria a las leyes constitucionales ni a la Declaración. El sistema constituye una poderosa protección en provecho del in- 
dividuo contra el arbitrio legislativo..." (DUGUIT, Traité, III, p. 641). A partir de fines del siglo XVIII la idea de esta superlegalidad de los textos constitucionales se extiende por el mundo, habiéndose obtenido en ciertos Estados la conclusión lógica de esta superlegalidad de la Constitución; se ha instituído un control de la constitucionalidad de la legislación. Un control de este género existía en América del Norte. Allí se desarrolló la doctrina del control judicial; este control actúa para cada caso concreto, y el Juez, cuando estima que la ley es inconstitucional, no la aplica al caso dado, pero la ley continúa en vigor". - "Esta institución del control constitucional es uno de los fenómenos de la racionalización del Poder. La supremacía del Poder constituyente, que los pueblos modernos han heredado de la Revolución francesa, tiene su expressión concreta en el control de la constitucionalidad de las leyes. Unicamente este control puede dar garantías reales de la legalidad superior de la Constitución y tambíen de las liberdades individuales. La técnica del Derecho constitucional es tal que el texto de la Constitución no puede sino sancionar el principio general de la liberdad individual, lo que obliga a veces a la introducción de reservas relativas a su limitación posible en matéria de legislación ordinaria, hallándonos aquí ante el problema más interesante del Derecho constitucional, ligado a las garantías de las liberdades del individuo. En cuanto que el legislador es libre, y en lo que concierne a las leyes limitativas de las libertades individuales, puede promulgar una ley contraria al principio proclamado por la Constitución, el control jurisdiccional de las leyes deve garantir lo que se llama Derechos del Hombre e del Ciudadano. Cuando la Revolución francesa formuló su Declaración, que constituye todavía hoy el catálogo-tipo de las libertades individuales, los hombres de aquela época no teníam aún el concepto jurídico del problema de 
las garantías de los derechos individuales. Con una fe ciega en el acierto de la voluntad general, creyendo que toda manifestación de la soberanía del pueblo era no solamente legal, sino ante todo razonable, no apercibieron el problema de las garantías reales de las libertades individuales. Veían estas garantías en la separación de Poderes, en el principio de la soberanía del pueblo y sobre todo en el principio de la legalidad. Pero este principio de la legalidad no puede ser considerado como la ínica garantia de las liberdades individuales; garantizando el individuo contra el arbitrio del Poder ejecutivo deja al ciudadano indefeso ante el del legislativo, capaz de promulgar una ley contraria al principio de la libertad individual proclamado por la Constitución. He aquí por qué el control de la constitucionalidad de las leyes es una garantía suplementaria de las libertades individuales". (Modernas Tendências Del Derecho Constitucional, trad. do francês por SABINO ALVAREZ GENDIN, 1. ${ }^{\mathrm{a}}$ ed., ps. 31-33).

Tal axioma jurídico, também designado como a "supremacia da constituição" (cf. JACOBSEN-LIPMAN, BARTHÉLEMY, DUES e HAURIOU - apud PINTO FERREIRA), é, em última análise, o nosso velho e conhecido princípio da hierarquia das leis, decantado por RUY BARBOSA: em primeiro lugar a Constituição Federal, originária do poder constituinte, soberano e absoluto no organizar o Estado; em segundo, as leis federais, desde que conformes com a super-lei; em terceiro, as constituições estaduais, formuladas de acôrdo com o modêlo federal; e, por último, as leis estaduais.

Merece conhecida, entretanto, a advertência que DUGUIT, já em 1923, quando da publicação do seu famoso "Traité", formulava sôbre 0 sistema constitucional fundado na "hierarquia das leis", ao acentuar que

“... é preciso que existam, no país, tribunais fortemente organizados, cuja independência e capacidade 
estejam acima de tôda suspeita, e que tenham o poder de recusar a aplicação de qualquer lei, que julguem contrária à Declaração dos Direitos ou à Constituição". (Op. cit., III, ps. 641-642).

"O princípio da supremacia constitucional" preleciona o ilustre catedrático da escola de Recife - "é reputado como uma pedra angular, em que assenta o edifício do moderno direito político. De feito, as regras constitucionais são dotadas de uma superioridade profunda com relação às demais normas jurídicas. Essa hierarquia se justifica, a fim de se melhor manter a estabilidade social do grupo, estabelecendo-se um sistema de preceitos básicos a que se submete a conduta coletiva". (PINTO FERREIRA, op. cit., p. 132).

14. A divisão dos poderes do Estado (legislativo, executivo e judiciário, harmônicos e independentes entre si) é outra ponderável garantia das liberdades individuais, consagrada pelos Estados de Direito, adeptos dessa técnica de especialização das funções administrativas.

Foi o sábio MONTESQUIEU quem sistematizou a teoria da divisão dos poderes estatais, já enunciada, em épocas antigas, por ARISTóTELES (Política) e mais modernamente por BODIN (que apenas sustentou a conveniência de separar a administração da justiça das atribuições do rei) e, ainda, pelo pai do liberalismo inglês (LOCKE), exaltando o famoso sistema, que se transformou em autêntico dogma, na filosofia política e nas constituições escritas, que surgiram do século XVIII em diante.

Elucida o autor do "Esprit des Lois", ao justificar a limitação do poder pelo próprio poder (le pouvoir arrête le pouvoir), não só como racional divisão da atividade administrativa, mas, também, a título de garantia das liberdades individuais contra os excessos e abusos do poder: 
"Em todo o Estado, há três espécies de poderes, o poder legislativo, o poder executivo das coisas que dependem do direito das gentes, e o poder executivo das que dependem do direito civil. Pelo primeiro o príncipe ou magistrado faz leis para algum tempo ou para sempre, e corrige ou abroga as que estão feitas. Pelo segundo, êle faz a paz ou a guerra, envia e recebe embaixadas, estabelece a ordem, prevê as invasões. Pelo terceiro, pune os crimes e julga os dissídios dos particulares. Chama-se à última o poder de julgar e à outra simplesmente o poder executivo do Estado". - "A liberdade política sòmente existe nos govêrnos moderados. Mas nem sempre ela existe nos govêrnos moderados. Só existe quando não se abusa do poder, mas é uma experiência eterna que todo homem que detém o poder é levado a dêle abusar: e vai até onde encontra limites. Quem o diria? A própria virtude precisa de limites. Para que se não abuse do poder é necessário que pela disposição das coisas o poder limite o poder". (Op. cit., liv. XI, cap. VI).

Vê-se, por aí, que a teoria da distinção dos poderes do Estado, a qual tem por objetivo limitar a esfera de competência de cada órgão estatal e impedir, dêsse modo, os perigos do absolutismo, quando eliminada ou, mesmo, desvirtuada na prática, traz como conseqüência um recrudescimento da estatolatria e “... um correspondente e progressivo eclipse da liberdade individual". (GONELLA, op. cit., p. 215).

15. A irretroatividade da lei, no concernente aos direitos adquiridos, nos quais estão compreendidos o ato jurídico perfeito e a coisa julgada, constitui mais uma expressiva conquista do direito público, proclamada e reconhecida em quase tôdas as cartas constitucionais. 
Qualquer sistema democrático, que se não queira afastar dos legítimos princípios que informam a estrutura sócio-jurídica dos Estados de Direito, não pode deixar de inscrever, em seu bôjo, essa importante garantia da liberdade. Opina incisivamente CARLOS MAXIMILIANO:

"é um princípio incontestado que domina a consciência jurídica universal”. (Comentários à Constituição Bras., v. III, p. 45).

A segurança do indivíduo, diante do Estado, dela depende fundamentalmente. Ouçamos esta advertência:

"Dái a uma legislatura o poder de votar leis retroativas, e ninguém está seguro; porque exposto ao domínio dela ficaria o passado inteiro de cada indivíduo. óbvio é, pois, que só de tiranos será digno fazer leis retroativas, e só de escravos obedecer-lhes". (WALKER - Introdution To American Law).

JOÃO BARBALHO, nos idos de 91, já nos afiançava:

"Si a lei pudesse ser com prejuízo dos direitos do cidadão aplicada a fatos passados antes dela, mal segura ver-se-ia a liberdade e o poder de legislar fôra o da tirania e opressão. Quem poderia estar tranquilo sôbre suas ações, si o que ontem praticou como ato permitido e legítimo pudesse ser hoje declarado pela autoridade pública como fato punível ou nulo? A liberdade, honra, vida e propriedade do cidadão viriam a ser um brinco nas mãos de legisladores mal inspirados e ninguém em suas ações, em seus negócios, sentir-se-ia garantido. É esta, como se vê, uma das mais importantes garantias individuais, ao mesmo passo que é um dos grandes princípios da ordem social e política. Sem ela, não seria possível termos - regime livre a que, como a mais alta aspiração nacional, alude o "Preâmbulo" da Constituição, a qual por isso impõe quer ao Congresso Nacional, quer às legislaturas dos Estados, a proibição dêste n. ${ }^{\circ}$ 3. E 
para efetividade de tal garantia, a magistratura, desde que é provocada pelos meios regulares, tem obrigação de declarar sem vigência e fóra de aplicações as leis federais ou dos Estados que acaso infrinjam à citada disposição constitucional (arts. 59, § 1. ${ }^{\circ}$, e $\left.60 a\right) "$. (Com. à Const. Bras.).

16. Não param aí, porém, as garantias das liberdades fundamentais do homem, realçando-se, dentre elas, o próprio regime representativo, que, "dentro de relatividade, é ainda a garantia essencial dos direitos individuais, sobretudo porque permite modificar as leis injustas e corrigir os abusos de poder, sem recurso ou violência". (DARCY AZAMBUJA, op. cit., p. 162).

Nos países de elevado padrão de educação política (como, v. g., os EE. UU. e a Suiça), na categoria de corolários do direito de sufrágio, existem, ainda, a iniciativa popular, o recall e o referendum, expressões de garantias das liberdades políticas dos cidadãos (4).

(4) A prática do referendum, nas suas várias e específicas modalidades, caracteriza, modernamente, a chamada democracia semi-direta, que não se mostra incompatível, de resto, com o sistema representativo. A Suíça, v. g., é pródiga quanto a êsse sistema político-governativo. E a Constituição Brasileira, de 18 de setembro de 1946, no seu art. $2 .^{\circ}$, cuida de caso típico de referendum quando estabelece que os "Estados podem incorporar-se entre si, subdividir-se ou desmembrar-se para se anexarem a outros ou formarem novos Estados, mediante voto das respectivas assembléias legislativas, plebiscito das populações diretamente interessadas e aprovação do Congresso Nacional". O nosso legislador constituinte, soberano, é certo, no organizar jurídica e politicamente o Estado, usou impròpriamente, todavia, do vocábulo plebiscito no texto. É que as hipóteses dessa reforma constitucional, reforma que diz de perto com a nossa estrutura federativa, exigem, na verdade, segundo NELSON DE SOUSA SAMPAIO, nada menos de "dois referenda: um popular e outro do Congresso Nacional. A impropriedade já vinha, aliás, na carta de 1937, art. 5., parágrafo único" (in "O Poder de Reforma Constitucional", Bahia, 1954, pág. 32 , nota n. ${ }^{\circ} 33$ ).

A Constituição do Paraná, promulgada em 1947, adotou o mesmo critério, nos casos de incorporação e anexação de Municípios (art. 132, par. único, segunda parte). 
17. Outros institutos jurídicos abrolham nos Estados de Direito, os quais se destinam ao resguardo da pessoa humana contra os excessos e os abusos de poder.

Entre êles avulta o habeas-corpus, universalmente consagrado como a garantia mais eficaz da liberdade de locomoção, típica actio popularis contra a violência ou coação. E o mandado de segurança, remédio legal, entre nós, da mesma gênese que o habeas-corpus, é endereçado à defesa de direitos certos e líquidos, não amparáveis pelo remédio heróico de proteção da liberdade física, sempre que tais direitos estejam ameaçados ou violados por atos ilegais ou abusivos de quaisquer autoridades (5).

Vem a pelo assinalar que, atentas as necessárias reservas oriundas das peculiaridades legislativas de cada país, o instituto do mandado de segurança, tal como vem inscrito na Constituição Brasileira, de 46 , se assemelha inteiramente ao recurso do juicio de amparo, existente e praticado no México, e tão bem compreendido e explicado por IGNACIO VALLARTA, no seu "Ensayo sobre el juicio de amparo y el writ of habeas-corpus" (6).

(5) Uma das funções precípuas, institucionais, mesmo, do Ministério Público, é a de velar permanentemente, como num dever específico, pela liberdade de ir e vir dos cidadãos. No exercício de uma típica ação popular, tradicionalmente aceita, qualquer cidadão pode impetrar, em seu favor ou no de outrem, por simples bilhete, habeas-corpus ao juiz. E o representante do Poder Judiciário é obrigado a processá-lo, podendo mandar vir imediatamente à sua presença o detido, para ouví-lo e ordenar o que julgar conveniente, a fim de conceder, ou não, a ordem liberatória. Ao M. P. do Estado do Paraná, segundo o disposto na Lei de Organização Judiciária, compete a atribuição de requerer habeas-corpus tôda vez que encontrar pessoa ilegalmente detida, para o que é obrigado a visitar permanentemente os presídios.

(6) A lei federal n. ${ }^{\circ} 1.533$, de 31 de dezembro de 1951, regulamentou entre nós o processo do writ. Êste diploma encerra algumas lacunas, já entregues ao exame do Congresso Nacional, como tivemos oportunidade de salientar em crônicas estampadas na secção forense da "Gazeta do Povo" sob o título "O Mandado de Segurança no Dirieto Brasileiro". A referida lei, contudo, vem tendo larga aplicação nos juízos e tribunais, desde que em pleno vigor em todo o território nacional. 
O nobilíssimo dogma do direito penal - nullum crimen, nulla poena sine lege - importa, igualmente, em expressiva garantia, "um anteparo da liberdade individual em face da expansiva autoridade do Estado", dogma incluido, desde a revolução francesa de 89 , como reação à estatolatria medieval, entre os direitos fundamentais do homem, e verdadeiro palladium da liberdade civil, segundo MEZGER. (Cf. HUNGRIA, Comentários ao Cód. Penal Bras., v. 1.․․ ps. 10-12).

18. No que tange ainda à justiça criminal, despontam vários outros institutos jurídicos, que se relacionam, ìntimamente, com as prerrogativas fundamentais do homem e do cidadão.

A Carta Magna do Brasil, promulgada a 18 de setembro de 1946, não se manteve infensa, em diversos dos seus preceitos, à proteção dos direitos da pessoa humana contra 0 arbítrio ou a ilegalidade na apreciação de seus atos e de sua conduta no convívio social. A presunção de inocência de qualquer acusado, trazido à barra dos juízes, quer singulares, quer coletivos, até que se lhe prove o crime pelos meios previstos em lei, é a idéia humana e generosa (art. 10 da Declaração Universal da ONU e art. 26 da Declaração Americana aprovada em Bogotá) que preside à discriminação dêsse sistema processualístico de garantias constitucionais que protegem a pessoa do imputado. (Cf. COOLEY, nas Constitucional Limitations). Em conseqüência, temos: a proibição do fôro privilegiado e de juízes e tribunais de exceção; a mais ampla defesa assegurada aos indiciados, com todos os meios e recursos essenciais a ela, desde a nota de culpa, que, assinada pela autoridade competente, com os nomes do acusador e das testemunhas, será entregue ao prêso dentro de vinte e quatro horas; a norma indeclinável da contraditoriedade na instruçã̃o criminal; a retroatividade, em favor do agente, da lei penal mais benigna (princípio da lex mitior); a comunicação imediata, à autoridade competente, da prisão ou detenção de qualquer pessoa, para a verificação de sua legalidade e, quando couber, a promoção da responsabilidade da autoridade coatora. Há mais: - a prisão de qualquer pessoa só poderá ocorrer em flagrante delito ou por ordem es- 
crita da autoridade competente, nos casos expressos em lei, assim como ninguém será levado à prisão, ou nela detido, se prestar fiança permitida pela legislação; e, ainda, não se admite a pena capital, ressalvadas as disposições da legislação militar em tempo de guerra, etc. (cf. art. 141, §§ 26, 25, 29, 22, 20, 21, 31). A manutenção do Tribunal do Júri, para o julgamento de certos e determinados delitos, envolve, por outro lado, mais uma manifestação democrática dêsse amplo conjunto de normas reguladoras das prerrogativas fundamentais do cidadão perante a justiça repressiva do Estado, quando acusado da prática de qualquer delito anteriormente definido e punido por lei.

19. No quadro do direito público brasileiro, consoante as linhas mestras do ordenamento constitucional de 1946, vamos encontrar, ainda, a ação popular de natureza civil, que pode ser considerada como uma das garantias fundamentais do cidadão brasileiro, para a defesa dos interêsses coletivos malferidos por atos de governantes ou administradores.

Ela vem inscrita, sob a epígrafe dos direitos e das garantias individuais, no parágrafo 38 do art. 141, nos seguintes têrmos:

"Qualquer cidadão será parte legítima, para pleitear a anulação ou a declaração de nulidade de atos lesivos do patrimônio da União, dos Estados, dos Municípios, das entidades autárquicas e das sociedades de economia mista (7).

A actio popularis, já prevista, aliás, pela Carta Política Brasileira de 1934 (n. ${ }^{\circ} 38$ do art. 113), constitui, não há negar,

(7) Acha-se em trânsito, na Câmara dos Deputados, projeto de lei destinado a regular a ação popular. 0 deputado BILAC PINTO apresentou substitutivo ao projeto, que tomou o número $2.466 / 52$. A Diretoria do Ensino Superior, do Ministério da Educação e Cultura, acaba de encaminhar o teor do mencionado substitutivo às Congregações de tôdas as Faculdades de Direito do país, para fins de estudo e parecer. 0 cânone constitucional permissivo, inscrito na categoria dos direitos e garantias constitucionais, é, porém, auto-aplicável, independentemente da legislação complementar, conforme está assentado pela jurisprudência, observando-se o rito ordinário previsto pelo Código de Processo Civil. 
autêntico direito público subjetivo, a ser exercido, perante o Poder Judiciário, tão só por cidadãos brasileiros, natos ou naturalizados.

0 preceito permissivo dessa espécie de ação, como faz notar PONTES DE MIRANDA, é de direito político, razão por que dela não poderão dispor os que estiverem com os seus atributos de cidadania suspensos ou perdidos, na forma do art. 135, $\S \S 1 .^{\circ}$ e $2 .^{\circ}$.

O fim específico da ação popular, que se não confunde nem pode ser substituida pelo mandado de segurança, é a anulação ou declaração de nulidade de atos lesivos do patrimônio das entidades de direito público e seus prolongamentos autárquicos ou para-estatais, sejam, ou não, nulos ou anuláveis os atos praticados pelos agentes da administração. Quer isso dizer que o cidadão só é parte legítima para a ação, quando e onde houver atos lesivos do patrimônio público. Fora daí, torna-se parte ilegítima, por exorbitar os limites permissivos para o impulsionamento da ação.

A origem da actio popularis remonta ao Direito Romano, tendo influenciado o direito positivo italiano, que a adotou sob caráter excepcional. MORTARA, discorrendo sôbre o instituto, realçou a sua natureza excepcional:

“É verdade que tal instituto a nossa organização processual só o acolheu por via de exceção, de modo a lhe não ser possível receber aplicações outras que as indicadas expressamente pelas leis. É que a tutela do interêsse comum, nas matérias e negócios que entendem com o bem geral, pertence normalmente aos órgãos constituidos para representarem a coletividade e seus direitos, nos limites das respectivas atribuições (eis a regra); mas essa norma se derroga nei casi specifici nei quali é permesso l'esercizio dell'azione popolare".

E COVIELLO, de sua vez, ao distinguir as ações em privadas $e$ populares, esclarece que

"as primeiras constituem a regra: são as exercita- 
das por determinadas pessoas em defesa dos seus próprios direitos. $\mathrm{E}$ as populares representam exceção: são aquelas que a lei, em determinados casos, permite ao particular exercitar, desde que o faça em defesa de um interêsse público". (Apud PAULO BARBOZA DE CAMPOS FILHO - Ensaio sôbre a Ação Popular).

Inegável é, portanto, o caráter especialíssimo da ação popular, não podendo ela, em conseqüência, ser usada para outros fins que não os expressamente previstos no mandamento constitucional. Afóra, é conveniente ressalvar, os casos de societas coeleris assinalados no art. 670 do Cód. de Proc. Civil, os quais envolvem indisfarçável interêsse público.

O interêsse cívico é a mola propulsora dessa espécie de ação. $O$ cidadão pleiteia não em seu próprio interêsse, mas no da coletividade. Age o indivíduo, assim, ut civis e na qualidade de membro da comunidade, postulando direta, imediatamente, a salvaguarda do interêsse geral, e só mediata, indiretamente, o seu interêsse individual, como partícipe da coletividade (8).

Mas, de qualquer maneira, a lesão que se busca reparar, desde que praticada contra o interêsse público, significa, por via oblíqua, uma lesão contra o interêsse individual. Pois que o patrimônio estatal é sagrado e de todos, contribuindo cada cidadão com a sua parcela de ajuda para a sua formação, quan-

(8) Nos debates orais, travados no $1^{\circ}$ Congresso Interamericano do $\mathrm{Mi}$ nistério Público, tivemos o ensêjo de salientar que, com relação à actio popularis de natureza civil e destinada, pela Constituição brasileira, à anulação ou à declaração de nulidade de qualquer ato lesivo do patrimônio da União, dos Estados, dos Municípios, das entidades autárquicas e das sociedades de economia mista, o Ministério Público - sem prejuízo, é claro, da legitimidade de parte atribuida a qualquer cidadão - deve também ter atribuições específicas para o impulsionamento dessa espécie de ação, cujo objetivo, como vimos, é o resguardo do interêsse público. Se qualquer cidadão - sustentámos naquele certame internacional - pode propôr, no sistema constitucional vigorante no Brasil, ação em juízo para pleitear a nulificação de ato lesivo do patrimônio da comunidade de que faz parte, praticado por agente do poder público, como negar-se essa salutar e poderosa atribuição ao Ministério Público, órgão da lei e fiscal de sua execução? 
do satisfaz aos seus encargos fiscais. $\mathrm{E}$ a pecunia pública deve ter, única e exclusivamente, uma imutável finalidade: a de ser aplicada em benefício dos superiores interêsses gerais!

20. O Supremo Estatuto de 1946, nas suas linhas estruturais, institui um regime democrático, de forma republicana e federativa, emanados todos os seus poderes da soberania popu-

A essência da organicidade política do Estado brasileiro repousa no pluripartidarismo, fundado êste, por sua vez, no sufrágio universal, obrigatório e secreto com representação proporcional (art. 134), mas deixou claro o constituinte nacional ser

"vedada a organização, o registro ou o funcionamento de qualquer partido político ou associação, cujo programa ou ação contrarie o regime democrático, baseado na pluralidade dos partidos e na garantia dos direitos fundamentais do homem", (art. $141 \S$ 13 - os grifos são nossos).

lar (preâmbulo e seu art. $1^{\circ}$ ).

A declaração concisa do $\S 1 .^{\circ}$ do art. 141 põe em realce o princípio de isonomia (igualdade com justiça para todos, segundo a antiga sabedoria helênica), não sendo tolerada, outrossim, a propaganda de guerra, de processos violentos para subverter a ordem política e social, ou de preconceitos de raças ou de classe (art. $141, \S 5 .^{\circ}$ ).

Os direitos e garantias fundamentais da pessoa humana em face do Estado, relativamente à inviolabilidade de todos os brasileiros e estrangeiros, quanto à vida, à liberdade, à segurança individual e à propriedade, estão cuidadosamente arrolados e definidos no citado art. 141 e seus parágrafos (quanto aos estrangeiros, desde que residentes no país).

Os preceitos relativos à proteção dos direitos sociais (concernentes à família, à educação, à cultura) se acham catalogados nos arts. 163 e seguintes; enquanto que aos trabalhadores são assegurados direitos específicos nos arts. 157 e seguintes, 
destacando-se, dentre êles, o pertinente à participação nos lucros das emprêsas, de acôrdo com o que for determinado em lei (9).

A ordem econômica - disciplina ainda o nosso código fundamental - deve ser organizada conforme os princípios de justiça social, conciliando a liberdade de iniciativa com a valorização do trabalho humano (art. 146 e sgts.), ficando, porém, o uso da propriedade condicionado ao bem-estar social. Mas a lei poderá, respeitado o direito à indenização por desapropriações por necessidade ou utilidade pública, ou por interêsse social, "promover a justa distribuição da propriedade, com igual oportunidade para todos" (art. 147). A todos é assegurado trabalho que possibilite existência digna. O labor, contudo, é considerado (par. único do art. 145) como uma obrigação social (10).

Consagra também a nossa Magna Carta o princípio segundo o qual a lei não poderá excluir da apreciação do Poder Judiciário qualquer lesão de direito individual (art. 141, § $4 .^{\circ}$ ).

Mas - acresce referir - a especificação dos direitos e garantias expressos na Constituição do Brasil não exclui outros direitos e garantias decorrentes do regime e dos princípios que ela adota (art. 144). Esta disposição - semelhante à da novíssima Lei Constitucional sancionada em 26 de outubro de 1951

(9) A regulamentação da importante matéria, consoante plano legal específico, na atualidade, depende tão só da clarividência do Senado da República, onde se acha em estudos há algum tempo.

(10) Também não se deve olvidar o preceito novo contido no art. 202 da Constituição de 1946: “Os tributos terão caráter pessoal, sempre que isso fôr possível, e serão graduados conforme a capacidade econômica do contribuinte". Trata-se do princípio da individualização do impôsto. $\mathrm{O}$ Estado, porém, "sob o pretexto de arrecadar as suas rendas, não deve levar o contribuinte à miséria", segundo refere THEMÍSTOCLES BRANDÃO CAVALCANTI (in "Constituição Federal Comentada", ed. José Konfino, vol. IV, pág. 222). Garantia, em suma, do indivíduo contra o leonismo fiscal.

Tal princípio veio rebustecer e completar a regra democrática segundo a qual nenhum tributo será exigido ou aumentado sem que a lei o estabeleça; nenhum será cobrado em cada exercício sem prévia autorização orçamentária, ressalvada, porém, a tarifa aduaneira e o impôsto lançado por motivo de guerra (cf. § 34 do art. 141). 
pela República Oriental do Uruguay (art. 72) e à emenda IX das adicionais à Constituição dos Estados Unidos da América do Norte - traduz a conhecida regra das garantias e direitos implícitos. A enumeração das liberdades ou direitos essenciais da pessoa humana não deve jamais ser encarada como supressiva ou denegatória de outros direitos não expressamente consignados e que se amoldem à idéia nuclear do regime democrático e aos princípios nele consagrados. Idêntico preceito é mencionado pelo art. 36 da Constituição da República Argentina, sancionada em 11 de março de 1949.

21. O totalitarismo de mística revolucionista (o vocábulo é usado por CALMON), como fenômeno conseqüente à hipertrofia da idéia de Estado, seja da esquerda, seja da direita, afigura-se-nos absolutamente incompatível com a dignidade da pessoa humana, porque absorvente, em última análise, dessa mesma dignidade.

Negando ao ser humano quaisquer direitos pessoas inalienáveis e imprescritíveis e situando tôda a sua atividade física e mental dentro do Estado, nada fora do Estado e tudo pelo Estado, pretende êsse regime que o homem seja totalmente absorvido pelo grupo, pela classe ou pela raça.

A atmosfera de igual oportunidade para todos e a liberdade de iniciativa privada, desde que condizentes com o interêsse geral, verdadeiros apanágios do Estado democrático, não existem no totalitarismo. 0 trabalho é ordenado e planificado pelo Estado, que tudo resolve, tudo orienta, tudo rìgidamente disciplina, enfim tudo faz, inclusive pensar pela massa despersonalizada, que não pode, nem de leve, raciocinar ou agir contràriamente à vontade do partido ou do ditador. Êste, "por sua vez", salienta FULTON SCHEEN,

"justifica-se, dizendo que é o bem do todo o que êle exige. A única moralidade, em tal esquema, é a moralidade do Estado; a única consciência é a consciência do Estado; o único fim é a glorficação da nação, da raça ou da classe. A liberdade nessa teoria 
reside não no homem, mas no Estado; direitos não nascem na alma, mas sim no grupo. 0 homem não é uma pessoa social, mas parte de um todo e como tal é meio para um fim". (Op. cit., p. 133).

Por isso mesmo é que a fórmula de Mussolini, de marcante sentido absorvente da personalidade do homem, se mostrava tão categórica e nulificante" "Tudo no Estado, nada fora do Estado, nada contra o Estado". Êsse malsinado totalitarismo político de fôrça e dominação, que tanto sangue e sacrifício custou ao mundo, chegava ao cúmulo de afirmar, pela palavra do Duce, que o Estado fascista "não se pode limitar às simples funções de mantenedor do mecanismo que limita a esfera das liberdades individuais. $E$ forma e norma interior, disciplina de tôda a personalidade. Tanto a vontade como a inteligência". ("La Doctrine du Fascime" - nossos os grifos).

Era, como se vê, o Estado-onipotente e despótico, única realidade soberana, controladora e incontrolada da vida temporal e espiritual do cidadão, desconhecendo-se, por completo, a outra realidade social eminente - o homem - na sua qualidade de criatura portadora de dignidade absoluta, indisponível e incomunicável, não dependente, para a sua existência, de qualquer édito ou preceito normativo construido pelo organismo estatal, quanto aos seus direitos humanos.

DARCY AZAMBUJA retrata, com firmeza e eloqüência, as características impuras das doutrinas totalitárias do comunismo e do nazismo:

"A finalidade fundamental com que se apresentam pode ser resumida em que pretendem resolver os problemas sociais e políticos, negando-os. Há oposição de classes, há luta entre capitalismo e operariado? Pois suprimam-se as classes e reduza-se a sociedade tôda a uma classe única: o proletariado, sob cuja ditadura o Estado será um simples instrumento para a implantação do comunismo. Foi o que os bolchevistas fizeram na Rússia. Há oposição de raças, de conceitos morais, jurídicos e políticos? Pois 
que haja uma só raȩa, uma só moral, um só direito, uma só política: a raça alemã, a moral, o direito e a política da raça alemã, encarnada e interpretada pelo Führer. É a doutrina do nacional socialismo, ou nazismo". (Op. cit., ps. 150-151).

Autênticos desvios, rudes e deshumanos, da verdadeira função disciplinadora do Estado, os totalitarismos representam um "colapso na civilização, um mergulho na barbárie". Regimes, em suma, irremediàvelmente inconciliáveis com a eminente dignidade do homem e degradantes senzalas políticas geradoras de opróbio e escravidão!

22. A democracia é a única expressão política verdadeiramente compatível com a dignidade da pessoa.

Nela as idéias de liberdade e preeminência dos direitos humanos encontram campo propício ao seu racional desenvolvimento e grandeza.

O homem, como unidade moral, social e econômica, destinado a viver junto com os outros homens em pacífica harmonia e cooperação mútua, recebe a idéia democrática de organização do poder como um imperativo irresistível a ressoar profundamente na sua razão e na sua consciência.

Daí o afirmar BARTHÉLEMY que o regime democrático se agiganta, na época em que vivemos, de profundas mutações sócio-políticas, na esteira dos fatos inevitáveis:

"Uma atração profunda, misteriosa, irresistível, poderosa e fatal como uma fôrça da natureza encaminha os povos para a democracia. Pode-se criticar o movimento democrático, mas deve-se levar em conta que isso constitui um trabalho tão vão como o de criticar o curso das estações ou a atração dos astros". (La compétence dans la démocratie).

Constitui princípio generoso e nìtidamente evolucionista, em busca da efetividade, tanto quanto possível, dos ideais de liberdade, igualdade civil e justiça social. 
A norma democrática de organização do Govêrno dá forma e substância ao Estado, tendo por finalidade precípua, não o próprio Estado, mas, sim, o homem em seus naturais e indiscutíveis atributos morais e sociais, atributos que nunca podem ser anulados ou absorvidos nem pela sociedade, nem pelo comando dessa mesma sociedade.

Todo poder - diz a Constituição Brasileira - emana do povo e em seu nome será exercido, o que equivale a dizer que a verdadeira democracia é um meio e encontra sua base, essencialmente, na própria personalidade humana. A origem etimológica da palavra isso mesmo nos ensina (Demos - Krateirn).

E, por outras palavras, o alto e histórico conteúdo do discurso proferido por LINCOLN em Gettysburg: govêrno do povo, pelo povo e para o povo.

Acentuando o caráter emocional do princípio, ROUSSEAU já o escrevera no Contrato Social "que se houvesse um povo de deuses o seu govêrno seria democrático".

Devemos buscar, porém, a realização de um sistema de freios e contrapesos, mas humano e sensível às realidades da vida contemporânea, tão rica de substâncias novas, repleta, contudo, de êrros econômicos e sociais que pedem soluções em favor, principalmente, dos fracos e humildes.

Hoje em dia, monta acentuar, já não existe clima para aquela democracia passiva, liberal, individualista e clássica, segundo a moda ditada pelo século XVIII, democracia passidista a que o Prof. GEORGES BURDEAU intitula de "democracia governada". (Science Polit., v. IV, p. 441).

Urge, pelo contrário, a prática efetiva de uma "democracia governante", isto é, de uma democracia ativa, executiva e dinâmica de nosso tempo. Democracia, não resta dúvida, de sentido eminentemente evolucionista, com base no pluripartidarismo e no regime representativo, e no seio da qual predomine, de fato e de direito, a vontade do povo em ambiente de "poder aberto", em que se admita o amplo e arejado debate das idéias e dos princípios, para o cotêjo esclarecedor dos prós e dos contras. 
"O princípio da democracia governante" - ensina ainda o prof. BURDEAU, em face do sistema de poder fechado "é o de que êle deve deixar esperança aos que não participam do seu exercício. As duas regras não se excluem, mas sua coexistência depende da sabedoria dos homens que, dispondo do Poder, aprendem a não usá-lo para matar a liberdade". (Op. cit., p. 480).

0 tipo essencialmente dinâmico de democracia, de resto, nunca deve deixar de proclamar e defender o valor absoluto da pessoa humana, cujo bem-estar moral, social e econômico visa a atingir através de aparelhamento governativo voltado sempre para a conquista do bem-comum, na defesa intransigente de todos e para que todos possam usufruir, segundo os seus méritos e talentos, uma vida decente e feliz.

A democracia operosa e vigilante, fazendo sentir a sua presença em ambiente de ordem e de equilíbrio entre a liberdade e a autoridade, para o aprimoramento da coexistência social, e "entendida como govêrno do povo pelo povo" - é o que professa, não sem algum laivo de dúvida, o Dr. MIGUEL REALE, da Faculdade de Direito da Universidade de São Paulo - "é um ideal, a expresão mais alta do ideal político, porque significa a Humanidade na condição - inatingível talvez - de só obedecer a si própria. $\mathrm{E}$ um rumo permanente, o imperativo do dever ser político". (Teoria do Direito e do Estado, S. Paulo, 1940).

O princípio se exalta e caracteriza, assim, por aquela fôrça que R. H. GABRIEL chama de "fé democrática", a qual aparece como

"um sistema de freios e contrapesos e equilíbrios no reino dos ideais". Sistema que "hace posible un equilibrio entre libertad y autoridad, entre la autonomía del individuo libre y la necesaria coerción del grupo organizado. La fe democrática es, pues, en essencia una filosofia del hombre". (Cf. MANUEL GARCIA-PELAYO, Derecho Constitucional Comparado, Madrid, 1950, p. 262). 
O sentido da dignidade da pessoa humana e da liberdade é, todavia, o alto e imperecível conteúdo do ideal democrático (cf. WAITE, no seu What is Democracy?), que se estriba no próprio homem e se transforma em um meio altamente organizado para servir e não desservir a sua fonte geratriz.

"Não idolatramos, entretanto, a democracia" - com acêrto exclama MACHADO PAUPÉRIO "como outros o fazem. Ela não é um fim em si, mas apenas um meio de realização do bem comum. Felizes os povos que, como o suíço, não fazem da democracia um ídolo demagógico, mas procuram vivê-la para melhor satisfazer ao único imperativo do Estado: servir à pessoa humana". (Revista Forense, v. 152, 1954, p. 16).

Filosofia humana, porque do homem, inquestionàvelmente, a sua origem, e destinada, num ambiente de equilíbrio e respeito ao direito de cada um e de todos, a propiciar meios de desenvolvimento do cidadão no meio social, a democracia objetiva, em têrmos políticos de organização do poder, estribada no consentimento dos governados, assegurar, em suma, a exeqüibilidade dos direitos inauferíveis do ser humano, para a preservação da sua vida, da sua liberdade e do seu anseio de procura da felicidade, em atmosfera de segurança moral, intelectual e material. Só assim o homem se aprimorará. E só assim protegido e assistido, e cooperando com tôdas as fôrças de suas mãos, do seu cérebro e do seu coração aberto às pulsações de justiça e solidariedade social, poderá o homem também conquistar, em bases concretas e estáveis, o direito de não ter medo. Não ter medo nem do homem, nem do próprio Estado!

Assim, o ideal democrático, quando efetivamente atingido ou aprimorado, construirá, tenhamos fé e esperança nos dias futuros, não a confusão de gente bruta dentro da jungle, em que o homem como que regressa àquele sórdido estado do homo homini lupus (o homem seria o lobo do próprio homem), segundo a velha concepção de HOBBES, mas, sim, a fusão fraterna da humanidade, num clima de liberdade, de concórdia e 
de tolerância, fundado precìpuamente na salvaguarda da eminente dignidade da pessoa humana, sob o seu tríplice e fundamental aspecto: o homo socialis, o homo oeconomicus e o homo sapiens.

\section{* * *}

23. À vista das considerações expendidas, podemos enterreirar tôda a matéria nas seguintes conclusões:

O homem é um ser moral e social, destinado a viver na sociedade em harmonia e cooperação com os seus semelhantes.

II

A sociedade, decorrente da intensa e inelutável vida gregária do homem, não tem, contudo, o poder de lhe anular ou absorver a personalidade, que constitui patrimônio sagrado e de indisponibilidade e incomunicabilidade absolutas.

III

A pessoa humana é um fim em si, e nunca um meio, dela defluindo tôdas as causas e razões geradoras do Direito, que é do homem e para o homem, seja para protegê-lo, seja para tolher as ações individuais nocivas ao interêsse geral.

\section{. IV}

Em tôda e qualquer organização social sobreleva a figura do homem, que "é o eixo e o fundamento da vida. Tudo há-de ser construido pelo homem, para o homem, e sôbre o homem. 0 Estado é organismo criado para serviço e segurança do homem. Destarte não se há-de dizer que o homem é para o Estado, senã̃o que o Estado é para o homem", consoante os verídicos conceitos de ANGEL OSóRIO. (Fundamientos de la Democracia Cristiana).

0 Estado é, pois, um meio e não um fim.

$\mathrm{V}$

Os direitos fundamentais absolutos (a inviolabilidade da vida, da liberdade pessoal, do domicílio e da correspondência) 
são de natureza supraestatal e, como tal, não se apresentam como criações da legislação positiva do Estado, desde que nascem com o próprio homem. Quanto a êsses direitos naturais e inalienáveis, à organização política cabe apenas o dever de proclamá-los e reconhecê-los solenemente em sua Constituição, para o seu legítimo e efetivo exercício no convívio social. Mas, nos Estados de Direito, em que predomina o princípio da superlegalidade constitucional, forçoso é observar que os demais direitos individuais, desde que proclamados ou resguardados pela Lei Magna, devem também ser considerados como fundamentais, pois a Constituição - ápice do ordenamento jurídico da nação politicamente organizada - tem o poder de fazer "fundamental o que não é (ou ainda não é) supraestatal", na escorreita lição de PONTES DE MIRANDA.

\section{VI}

A liberdade individual, no mundo moderno, não constitui poder ilimitado de ação física do homem. 0 seu conteúdo é não só moral como social. Com os seus justos limites traçados ou restringidos pelas exigências do bem comum, ela representa faculdade que pode e deve ser regulamentada sábia e equilibradamente pela lei, pelo menos na medida que se torne necessária para que a liberdade de cada um não venha a prejudicar a dos demais. $\mathrm{E}$ é certo que ninguém pode ser obrigado a fazer ou deixar de fazer alguma coisa senão em virtude de lei (cf. $\S 2 .^{\circ}$ do art. 141 da Const. Brasileira).

\section{VII}

A autoridade, de sua vez, não é poder de mando absoluto ou despótico. Não deve descambar para a compressão de qualquer espécie, nem tampouco para a dominação injusta ou o abuso de poder. Os seus limites devem ser demarcados pela lei e, esta, deve precatar as prerrogativas inerentes à personalidade humana e os interêsses da ordem pública.

\section{VIII}

O princípio de racionalização do poder (M. GUETZÉVIT$\mathrm{CH})$ "identifica-se com o princípio de democracia e com o princípio de Estado de Dierito". E êste, por seu lado, sendo desti- 
nado fundamentalmente à defesa e à assistência da pessoa do homem nas suas justas aspirações de aprimoramento moral, intelectual e físico, deve realizar-se por intermédio de uma organização que se distinga "por dois traços: 1) limitação juridica do arbítrio do poder público; 2) estabilidade jurídica das garantias individuais. Não se pode admitir o progresso político, desde que falte alguma destas condições, das quais a segunda é uma conseqüência da primeira. E. sendo o arbítrio político incompatível com a segurança individual, pode-se dizer que o traço prático pelo qual se reconhece o Estado de Direito é o gráu de garantia de que são cercados os indivíduos". (Cf. QUEIROZ LIMA, Teoria do Estado, p. 57).

\section{IX}

Os totalitarismos, quaisquer que sejam, estereotipam regimes de fôrça e dominação, inconciliáveis com a inconfundível dignidade da pessoa humana.

\section{$\mathrm{X}$}

É inegável o valor da democracia social e cristã, onde o homem seja convenientemente tratado e considerado como criatura portadora de deveres e direitos correlativos na sociedade; mas democracia de estilo atuante, dinâmico e realizador, no sentido da solução dos multivários problemas da pessoa humana e da coletividade por meio da educação, da cultura, dos valores morais e espirituais, bem como por meio do trabalho edificante e benfazêjo. Deve ser dotada, para tanto, de cada vez mais perfeita e eficiente organização administrativa, na qual deve destacar-se um aparelhamento judiciário em condições de assegurar, com justeza, imparcialidade e sabedoria, a inviolabilidade dos direitos fundamentais do cidadão. (Cf. RANELETI, Instituzioni Di Diritto Publico, 1929, p. 105).

A democracia, exercitada por homens-bons, é o ideal político-governativo inteiramente compatível com a personalidade humana e ambiente propício ao seu desenvolvimento e grandeza (11).

(11) EDUARDO BENES, ex-presidente da Tchecoslováquia, declarou que "a democracia não é apenas uma questão de instituições democráticas mais perfeitas, mas, antes de tudo, uma questão de homens de- 


\section{XI}

O problema, senão o drama, da democracia na hora que passa é o do processamento, conciliação e cristalização da média das tendências e dos direitos, velhos e novos, que não raro se conflitam em exacerbada e inquietante luta das variantes sociais, em busca da preeminência política. A essa disputa e concorrência das tendências não pode ficar ausente o Estado, que preside ao complexo social, intervindo eficaz e prudentemente, dentro da dosagem necessária, na procura do justo equilíbrio entre o individual e o social, só realizável através da preservação dos inauferíveis e imutáveis atributos da eminente personalidade do homem, como grande fôrça niveladora e frenadora dos anseios e das expansões humanas em sociedade.

\section{CONCLUSIONS}

1. L'homme est un être moral et social, destiné à vivre en société en harmonie et coopération avec ses semblabes.

2. La société, qui résulte des tendances grégaires de l'homme, n'a toutefois pas la puissance d'anéantir en lui la personnalité, ou de l'absorber, étant donné que la personnalité constitue son patrimoine sacré, absolument inaliénable et indisponible.

3. La personne humaine est une fin e non un moyen. Toutes les causes et raisons du Droit découlent de la personne, soit en ce qui concerne la protection de l'individu, soit en ce qui concerne la prohibition d'actions nuisibles à l'intérêt général.

4. L'homme prédomine en toute organisition humaine, étant donné qu'il "est l'axe et le fondement de la vie. Tout doit être bâti par l'homme, pour l'homme et autour de l'homme. L'Etat est un organisme créé pour son service et sa sureté. Voi-

mocráticos mais perfeitos" (apud WILSON MARTINS, no seu substancioso ensaio "Introdução à Democracia Brasileira", editôra Globo, pág. 89). 
là pourquoi on ne peut dire que l'homme est pour l'Etat, mais que l'Etat est pour l'homme", d'après les remarques d'Angel Osorio (Fundamientos de la Democracia Cristiana). L'Etat est donc un moyen et non une fin.

5. Les droits fundamentaux absoluts (l'inviolabilité de la vie, de la liberté, du domicile et de la correspondance) sont de nature super-étatale, n'étant donc aucunement des créatinos de la législation positive de l'Etat, vu qu'ils naissent avec l'homme même. L'organisation politique ne doit que les proclamer et les reconnaitre solennellement dans la Constitution, pour permettre leur exercice légitime et effectif dans la vie sociale. Mais, dans les Etats des Droits, où prédomine le principe de la super-légalité constitutionelle, il faut observer que les autres droits individuells, dès qu'ils soient proclamés par la Loi Suprème, ils doivent être aussi considerés comme fundamentaux, dès que la Constitution - le point culminent de l'ordre juridique de la nation - a le pouvoir de rendre "fundamental ce qui ne l'est pas (ou ne l'est pas encore) super-étatale", dans la magistrale leçon de PONTES DE MIRANDA.

6. Dans le monde moderne, la liberté individuelle n'est pas sans limites. Son contenu est en même temps moral et social. Son étendue étant déterminé par les exigences du bien commun, ele est une faculté qui peut et doit être réglée par la loi, du moins dans la mesure où cela s'avère nécessaire pour que la liberté de chacun ne porte pas préjudice à la liberté d'autrui. Il est bien vrai que personne ne peut être contraint à faire ou à ne pas faire une chose sans une loi préalable qui crée l'obligation (cf. $\S 2 .^{\circ}$, de l'art. 141 de la Const. Brésiliènne).

7. L'autorité, de son côté, n'est pas un pouvoir tyrannique ou despotique. Elle ne doit pas servir à l'oppression, ni à la domination injuste ou à l'abus du pouvoir. Ses limites doivent être fixées par la loi et celle-ci doit viser aux atributs de la personne humaine et les intérêts de l'ordre publique.

8. Le principe de la rationalisation du pouvoir (M. GUETZEVITCH) "s'identifie pleinement avec le principe de la démocratie et avec le principe de l'Etat de Droit". Celui-ci, de 
son côté, destiné à la défense et à l'assistance de la personne humaine, dans ses justes aspirations au perfectionnement moral, intellectuel et physique, doit se réaliser à travers une organisation qui obéisse à deux principes: “1) la limitation juridique du pouvoir publique arbitráire; 2) la permanence juridique des garanties individuelles. Le deuxième est une conséquence du premier et faute de ces conditions on ne peut pas admettre le progrès politique. Etant donné que le pouvoir arbitraire est incompatible avec la sureté individuelle, on peut dire que le signal pratique par lequel on reconnait l'Etat de Droit est le degré de garantie dont on entoure les individus". (Cf. QUEIROZ LIMA - Teoria do Estado, p. 57).

9. Tous les régimes totalitaires sont des régimes de force et domination, où la dignité de la personne humaine ne peut pas trouver son climat.

10. On ne peut pas nier valeur de la démocratie sociale et chrétienne, dans laquelle l'homme est regardé comme sujet de devoirs et de droits. Il faut, toutefois, qu'elle soit une démocratie active, dynamique et réalisatrice, proposée à la solution des multiples problèmes de la personne humaine et de la collectivité, par l'intermédiaire de l'éducation, de la culture, des valeurs morales et spirituelles et du travail construtif et bienfaisant. On doit la doter d'une organisation administrative parfaite et efficace, en s'appuyant sur un organisme judiciaire capable d'assurer, en toute justice, impartialité et sagesse, l'inviolabilité des droits fondamentaux du citoyen. (Cf. RANELETTI - Istituzioni di Diritto Publico, 1929, p. 105). La démocratie est le seul idéal politico-administratif, exercé par des hommes capables et dignes, compatible avec la personne humaine et l'atmosphere propice a son developpement et grandeur.

11. Le problème, ou peut être le drame de la démocratie de nos jours, est celui de lácheminement, de la conciliation et de la cristallisation d'une moyenne de tendances et de droits, vieux et nouveaux, dont on voit trop souvent la lutte pour la domination politique. L'Etat ne peut pas se maintenir indifférent à cette lutıe, et dort, au contraire, intervenir activement 
dans la mesure du nécessaire, à la recherche d'un juste équilibre entre l'individuel et le social. Cet équilibre ne sera atteint que par la préservation des caractères qui distinguent la personnalité de l'homme, en tant que force égalitaire et de freinage aux desirs et aux expansions humaines en société.

\section{CONCLUSIONS}

1. Man is a social and moral being, designed to live in the society in harmony and working together with all his ressembling.

2. The society, because of the intense and inelutable gregarions life of mankind, has not however the right to rescind or to absorb the personality, that constitutes sacred patrimony of entire indisputableness and incommunicability.

3. The human being is an end in himself and never a way, coming from him all the causes and arguments of Right, which is from man and to man, as to protect him, as to forbid his individual actions hurtful to the general interest.

4. In all and anyone social organization it overcomes the human being, the center and reason of life. The State is an organism founded to man's service and safety. Thus one may not say that man is to the State, but the State is to the man, according to the true principles of Angel Osório. (Fundamientos de la Democracia Christiana). Thus, the State is a way and not an end.

5. The fundamental and absolute rights (inviolability of life, personal liberty, home and correspondence), are above State, and are not presented as creations of positive legislation of the State, because they come with the own man. Whatever to these natural and inalienable rights, to the politic organizations is contained only the duty to proclaim and recognise them pompously in its Constitution, to his lawful and effective practice in the social familiarity. But, in the States of Right where 
prevails the principle of constitutional supremacy, it is necessary to see that the other individual rights, since proclaimed und preserved by the Great Law, they must be considered as fundamental ones, for a Constitution, top of the juridical arrangement of a nation politicly organized, it has the power of making fundamental what is not (or what is not yet) overstatual, according to the outstanding lesson of Mr. PONTES DE MIRANDA.

6. Newdays, the human liberty, does not constitute un limited power of physic action of the man. Its content, is not only moral, but also social. In its right limits traced or confined by the commons well's exigences, it represents the faculty that may and ought to be ruled wisely by the law, for the liberty of every one, don't prejudice the liberty of the others. And, for sure, nobody can be obliged to do or not to do something but according to the law (cf. $2 \mathrm{nd}$. paragraph of the article number 141, of the Brazilian Constitution).

7. Authority, by its turn, it's not power of absolute ordering or despotic one, it must not fell in the oppression of any kind, either in the unfair domination or the abuse of power. Its limits must follow the law, and, this must support the arks of human personality and the interests of public life.

8. The principle of rationalization of power (M. GUETZEVITCH) "gets identified with the principle of democracy and with the principle of the State of Right". And, this by its turn, as it is destinated mainly to the defense and to the help of the human being in his fair wishes of moral improvement, intelectual and physic ones, must be realized through an organization which distinguish itself by two points: 1) juridic limitation of will of public power; 2) juridic steadiness of individual garanties. We may not addmit politic progress, since there is a lac of one those conditions, among which, the second is a consequence of the first. And, since the politic will is incompatible whith individual safety, we may say that the practicle by which we recognize the "State of Right" is the degree of garanty of what are enclosed men. (Cf. QUEIROZ LIMA, Teoria do Estado, pg. 57). 
9. Totalitarism,be as it may, represent sistems of force and oppression, incompatible with the unconfuseble dignity of human being.

10. It is undeniable the value of the social and Christian democracy, where the man is conveniently used and conducted as a creature who has corelative jobs and rights in social relations, but democracy of an useful style, dymanic and realizer, in the meaning of the solution of several problems of human being and collectivity through education, culture, moral and spiritual values, and also through building up a good work. It must be endowed for this, by a more perfect and more efficient administrative organization, where it must excel a juridic organism in conditions to safe, with accuracy, impartiality and wisdom the inviolability of the fundamental citizen's rights. (Cf. RANELETI, Istituzioni Di Diritto Publico, 1929, pg. 105).

Democracy, exerced by good men, is the politic and govermental ideal, entirely according to the human personality and favourable ambient to its improvement and greatness.

11. The problem, otherwise the drame of the democracy nowadays, it is the makingup of the process, settlement and crystallization in an average of the tendencies and rights, old and new ones, which frequently struggle in an intense and an easy fight of social variants, looking for political pre-eminence. To this fight and adversities of the tendencies the State must not be out that, which drives the social complexe, acting usefully and prudently into the right measure in looking for fair equilibrium between the individual and the social, only possible by the perservation of the unchangeble attributs of the eminent human personality, as a great leveller and holder force of wishes and human expansions in social relations. 
$A N E X O$ :

\section{DECLARAÇÃO AMERICANA DOS DIREITOS E DEVERES DO HOMEM}

(Aprovada na cidade de Bogotá em maio de 1948)

(*) A IX Conferência Internacional Americana,

Considerando:

Que os Povos Americanos dignificaram a pessoa humana e que suas constituições nacionais reconhecem que as instituições jurídicas e políticas, que regem a vida em sociedade, têm como finalidade principal a proteção dos direitos essenciais do homem e a criação de circunstâncias que lhe permitam progredir espiritual e materialmente e alcançar a felicidade;

Que, em repetidas ocasiões, os Estados Americanos reconheceram que os direitos essenciais do homem não derivam do fato de ser êle cidadão de determinado Estado, mas sim do fato dos direitos terem como base os atributos da pessoa humana;

Que a proteção internacional dos direitos do homem deve ser a orientação principal do direito americano em evolução;

Que a consagração americana dos direitos essenciais do homem, unida às garantias oferecidas pelo regime interno dos Estados, estabelece o sistema inicial de proteção que os Estados Americanos consideram adequado às atuais circunstâncias sociais e jurídicas, não deixando de reconhecer, porém, que deverão fortalecê-lo cada vez mais no terreno internaiconal, à medida que essas circunstâncias se tornem mais propícias,

Resolve:

adotar a seguinte

DECLARAÇÃO AMERICANA DOS DIREITOS E DEVERES DO HOMEM

\section{Preâmbulo}

Todos os homens nascem livres e iguais em dignidade e direitos e, como são dotados pela natureza de razão e consciência, devem proceder fraternalmente uns para com os outros.

(*) Texto constante da ata de encerramento dos trabalhos da IX Conferência Internacional Americana. 
O cumprimento do dever de cada um é exigência do direito de todos. Direitos e deveres integram-se correlativamente em tôda a atividade social e política do homem. Se os direitos exaltam a liberdade individual, os deveres exprimem a dignidade dessa liberdade.

Os deveres de ordem jurídica dependem da existência anterior de outros de ordem moral, que apóiam os primeiros conceptualmente e os fundamentam.

E dever do homem servir o espírito com tôdas as suas faculdades e todos os seus recursos, porque o espírito é a finalidade suprema da existência humana e a sua máxima categoria.

E dever do homem exercer, manter e estimular a cultura por todos os meios ao seu alcance, porque a cultura é a mais elevada expressão social e histórica do espírito.

$\mathrm{E}$, visto que a moral e as boas maneiras constituem a mais nobre manifestação da cultura, é dever de todo homem acatar-lhes os princípios.

\section{CAPÍTULO PRIMEIRO}

DIREITOS

Direito à vida, à liberdade, à segurança e integridade da pessoa.

Artigo I. Todo ser humano tem direito à vida, à liberdade e à segurança de sua pessoa.

Direitos de igualdade perante a lei.

Artigo II. Tôdas as pessoas são iguais perante a lei e têm os direitos e deveres consagrados nesta declaração, sem distinção de raça, sexo, língua, crença ou qualquer outra.

Direito à liberdade religiosa e de culto.

Artigo III. Tôda pessoa tem o direito de professar livremente uma crença religiosa e de manifestá-la e praticá-la pública e particularmente.

Direito de liberdade de investigação, opinião, expressão e difusão.

Artigo IV. Tôda pessoa tem o direito à liberdade de investigação, de opinião e de expressão e difusão do pensamento, por qualquer meio. e familiar.

Direito à proteção da honra, da reputação pessoal e da vida particular

Artigo V. Tôda pessoa tem direito à proteção da lei contra os ataques abusivos à sua honra, à sua reputação e à sua vida particular e familiar.

Direito à constituição e proteção da família.

Artigo VI. Tôda pessoa tem direito a constituir família, elemento fundamental da sociedade e a receber proteção para ela. 
Direito de proteção à maternidade e à infância.

Artigo VII. Tôda mulher em estado de gravidez ou em época de lactação, assim como tôda criança, têm direito à proteção, cuidados e auxílios especiais.

Direito de residência e trânsito.

Artigo VIII. Tôda pessoa tem o direito de fixar sua residência no território do Estado de que é nacional, de transitar por êle livremente e de não abandoná-lo senão por sua própria vontade.

Direito à preservação da saúde e ao bem-estar.

Artigo IX. Tôda pessoa tem direito à inviolabilidade do seu domicílio.

Direito à inviolabilidade e circulação da correspondência.

Artigo X. Tôda pessoa tem o direito à inviolabilidade e circulação dả sua correspondência.

Direito à preservação da saúde e ao bem-estar.

Artigo XI. Tôda pessoa tem direito a que sua saúde seja resguardada por medidas sanitárias e sociais relativas à alimentação, roupas, habitação e cuidados médicos correspondentes ao nível permitido pelos recursos públicos e os da coletividade.

Direito à educação.

Artigo XII. Tôda pessoa tem direito à educação, que deve inspirar-se nos princípios de liberdade, moralidade e solidariedade humana.

Tem, outrossim, direito a que, por meio dessa educação, lhe seja proporcionado o preparo para subsistir de uma maneira digna, para melhorar o seu nível de vida e para poder ser útil à sociedade.

$O$ direito à eđucação compreende o de igualdade de oportunidade em todos os casos, de acôrdo com os dons naturais, os méritos e o desejo de aproveitar os recursos que possam proporcionar a coletividade e o Estado.

Tôda pessoa tem o direito de que lhe seja ministrada gratuitamente, pelo menos, a instrução primária.

Direito aos benefícios da cultura.

Artigo XIII. Tôda pessoa tem o direito de tomar parte na vida cultural da coletividade, de gozar das artes e de desfrutar dos benefícios resultantes do progresso intelectual e, especialmente, das descobertas científicas.

Tem o direito, outrossim, de ser protegida em seus interêsses morais e materiais no que se refere às invenções, obras literárias, científicas ou artísticas de sua autoria.

Direito ao trabalho e a uma justa retribuição. 
Artigo XIV. Tôda pessoa tem direito ao trabalho em condições dignas e o de seguir livremente sua vocação, na medida em que fôr permitido pelas oportunidades de emprêgo existentes.

Tôda pessoa que trabalha tem o direito de receber uma remuneração que, em relação à sua capacidade de trabalho e habilidade, lhe garanta um nível de vida conveniente para si mesma e para sua família.

Direito ao descanso e ao seu aproveitamento.

Artigo XV. Tôda pessoa tem direito ao descanso, ao recreio honesto e à oportunidade de aproveitar ùtilmente o seu tempo livre em benefícío de seu melhoramento espiritual, cultural e físico.

Direito à previdência social.

Artigo XVI. Tôda pessoa tem direito à previdência social de modo a ficar protegida contra as conseqüências do desemprêgo, da velhice e da incapacidade que, provenientes de qualquer causa alheia à sua vontade, a impossibilitem física ou mentalmente de obter meios de subsistência.

Direito de reconhecimento da personalidade jurídica e dos direitos civís.

Artigo XVII. Tôda pessoa tem direito a ser reconhecida, seja onde fôr, como pessoa com direitos e obrigações, e a gozar dos direitos civís fundamentais.

\section{Direito à justiça.}

Artigo XVIII. Tôda pessoa pode recorrer aos tribunais para fazer respeitar os seus direitos. Deve poder contar, outrossim, com processo simples e breve, mediante o qual a justiça a proteja contra atos de autoridade que violem, em seu prejuízo, qualquer dos direitos fundamentais consagrados constitucionalmente.

Direito à nacionalidade.

Artigo XIX. Tôda pessoa tem direito à nacionalidade que legalmente lhe corresponda, podendo mudá-la, se assim o desejar, pela de qualquer outro país que estiver disposto a concedê-la.

Direito de sufrágio e de participação no govêrno.

Artigo XX. Tôda pessoa, legalmente capacitada, tem o direito de tomar parte no govêrno do seu país, quer diretamente, quer através de seus representatnes, e de participar das eleições, que se processarão por voto secreto, de uma maneira genuína, periódica e livre.

\section{Direito de reunião.}

Artigo XXI. Tôda pessoa tem o direito de se reunir pacificamente com outras, em manifestação pública, ou em assembléia transitória, em relação com seus interêsses comuns, de qualquer natureza que sejam. 
Direito de associação.

Artigo XXII. Tôda pessoa tem o direito de se associar com outras afim de promover, exercer e proteger os seus interêsses legítimos, de ordem política, econômica, religiosa, social, cultural, profissional, sindical ou de qualquer outra natureza.

Direito de propriedade.

Artigo XXIII. Tôda pessoa tem direito à propriedade particular correspondente às necessidades essenciais de uma vida decente, e que contribua a manter a dignidade da pessoa e do lar.

Direito de petição.

Artigo XXIV. Tôda pessoa tem o direito de apresentar petições respeitosas a qualquer autoridade competente, quer por motivo de interêsse geral, quer de interêsse particular, assim como o de obter uma solução rápida.

Direito de proteção contra prisão arbitrária.

Artigo XXV. Ninguém pode ser privado da sua liberdade, a não ser nos casos previstos pelas leis e segundo as praxes estabelecidas pelas leis já existentes.

Ninguém pode ser prêso por deixar de cumprir obrigações de natureza claramente civil.

Todo indivíduo, que tenha sido privado da sua liberdade, tem o direito de que o juiz verifique sem demora a legalidade da medida, e de que o julgue sem protelação injustificada, ou, no caso contrário, de ser pôsto em liberdade. Tem também direito a um tratamento humano durante 0 tempo em que o privarem da sua liberdade.

Direito a processo regular.

Artigo XXVI. Parte-se do princípio que todo acusado é inocente, até provar-se-lhe a culpabilidade.

Tôda pessoa acusada de um delito tem o direito de ser ouvida numa forma imparcial e pública, de ser julgada por tribunais já estabelecidos de acôrdo com leis preexistentes, e de que se lhe não inflijam penas cruéis, infamantes ou inusitadas.

Direito de asilo.

Artigo XXVII. Tôda pessoa tem o direito de procurar e receber asilo em território estrangeiro, em caso de perseguição que não seja motivada por delitos de direito comum, e de acôrdo com a legislação de cada país e com os convênios internacionais.

Alcance dos direitos do homem.

Artigo XXVIII. Os direitos do homem estão limitados pelos direitos do próximo, pela segurança de todos e pelas justas exigências do bem-estar e do desenvolvimento democrático. 


\section{CAPÍTULO SEGUNDO}

\section{N..... DEVERES}

Deveres perante a sociedade.

Artigo XXIX: 0 indivíduo tem o dever de conviver com os demais de maneira que todos e cada um possam formar e desenvolver integralmente a sua personalidade.

Deveres para com os filhos e os pais.

Artigo XXX. Tôda pessoa tem o dever de auxiliar, alimentar, educar e amparar os seus filhos menores de idade, e os filhos têm o dever de honrar sempre os seus pais e de os auxiliar, alimentar e amparar sempre que precisarem.

Deveres de instrução.

Artigo XXXI. Tôda pessoa tem o dever de adquirir, pelo menos, a instrução primária.

Dever do sufrágio.

Artigo XXXII. Tôda pessoa tem o dever de votar nas eleições populares do país de que fôr nacional, quando estiver legalmente habilitada para isso.

Dever de obediência à lei.

Artigo XXXIII. Tôda pessoa tem o dever de obedecer à lei e aos demais mandamentos legítimos das autoridades do país onde se encontrar.

Dever de servir a coletividade e a nação.

Artigo XXXIV. Tôda pessoa devidamente habilitada tem o dever de prestar os serviços civís e militares que a pátria exija para a sua defesa e conservação, e, no caso de calamidade pública, os serviços civís que estiverem dentro de suas possibilidades.

Da mesma forma tem o dever de desempenhar os cargos de eleição popular de que fôr incumbida no Estado de que fôr nacional.

Deveres de assistência e previdência sociais.

Artigo XXXV. Tôda pessoa está obrigada a cooperar com o Estado e com a coletividade na assistência e previdência sociais, de acôrdo com as suas possibilidades e com as circunstâncias.

Dever de pagar impostos.

Artigo XXXVI. Tôda pessoa tem o dever de pagar os impostos estabelecidos pela lei para a manutenção dos serviços públicos.

Dever do trabalho.

Artigo XXXVII. Tôda pessoa tem o dever de trabalhar, dentro das suas capacidades e possibilidades, a fim de obter os recursos para a sua subsistência ou em benefício da coletividade. 
Dever de se abster de atividades políticas em países estrangeiros.

Artigo XXXVIII. Todo estrangeiro tem o dever de se abster de tomar parte nas atividades políticas que, de acôrdo com a lei, sejam privativas dos cidadãos do Estado onde se encontrar.

\section{DECLARAÇÃO UNIVERSAL DOS DIREITOS DO HOMEM}

\section{(Aprovada em Resolução da III Sessão ordinária da Assembléia Geral das Nações Unidas a 6 de dezembro de 1948) \\ PREÂMBULO}

(*) Considerando que o reconhecimento da dignidade inerente a todos os membros da família humana e de seus direitos iguais e inalienáveis é o fundamento da liberdade, da justiça e da paz no mundo,

Considerando que o desprêzo e o desrespeito pelos direitos do homem resultaram em atos bárbaros que ultrajaram a consciência da Humanidade e que o advento de um mundo em que os homens gozem de liberdade de palavra, de crença e da liberdade de viverem a salvo do temor e da necessidade foi proclamado como a mais alta aspiração do homem comum,

Considerando ser essencial que os direitos do homem sejam protegidos pelo império da lei, para que o homem não seja compelido, como último recurso, à rebelião contra a tirania e a opressão,

Considerando ser essencial promover o desenvolvimento de relações amistosas entre as nações,

Considerando que os povos das Nações Unidas reafirmaram, na Carta, sua fé nos 'direitos fundamentais do homem, na dignidade e no valor da pessoa humana e na igualdade de direitos do homem e da mulher, e que decidiram promover o progresso social e melhores condições de vida em uma liberdade mais ampla.

Considerando que os Estados Membros se comprometeram a promover, em cooperação com as Nações Unidas, o respeito universal aos direitos e liberdades fundamentais do homem e a observância dêsses direitos e liberdades,

Considerando que uma compreensão comum desses direitos e liberdades é da mais alta importância para o pleno cumprimento dêsse compromisso,

(*) Texto completo e autorizado, segundo divulgação feita pelo Departamento de Informação Pública da ONU. 
Agora portanto A ASSEMBLÉIA GERAL proclama

A PRESENTE DECLARAÇÃO UNIVERSAL DOS DIREITOS DO HOMEM como o ideal comum a ser atingido por todos os povos e tôdas as nações, com o objetivo de que cada indivíduo e cada órgão da sociedade, tendo sempre em mente esta Declaração, se esforce, através do ensino e da educação, por promover o respeito a êsses direitos e liberdades, e, pela adoção de medidas progressivas de caráter nacional e internacional, por assegurar o seu reconhecimento e a sua observância universais e efetivos, tanto entre os povos dos próprios Estados Membros, quanto entre os povos dos territórios sob sua jurisdição.

Atrigo I. Todos os homens nascem livres e iguais em dignidade e direitos. São dotados de razão e consciência e devem agir em relação uns aos outros com espírito de fraternidade.

Artigo I. Todos os homens nascem livres e iguais em dignidade e die as liberdades estabelecidos nesta Declaração, sem distinção de qualquer espécie, seja de raça, côr, sexo, língua, religião, opinião política ou de outra natureza, origem nacional ou social, riqueza, nascimento, ou qualquer outra condição.

2 - Não será também feita nenhuma distinção fundada na condição política, jurídica ou internacional do país ou território a que pertença uma pessoa, quer se trate de um território independente, sob tutela, sem govêrno próprio, quer sujeito a qualquer outra limitação de soberania.

Artigo III. Todo homem tem direito à vida, à liberdade e à segurança pessoal.

Artigo IV. Ninguém será mantido em escravidão ou servidão; a escravidão e o tráfico de escravos serão proibidos em tôdas as suas formas.

Artigo V. Ninguém será submetido a tortura, nem a tratamento ou castigo cruel, desumano ou degradante.

Artigo VI. Todo homem tem o direito de ser, em todos os lugares, reconhecido como pessoa perante a lei.

Artigo VII. Todos são iguais perante a lei e têm direito, sem qualquer distinção, a igual proteção da lei. Todos têm direito a igual proteção contra qualquer discriminação que viole a presente Declaração e contra qualquer incitamento a tal discriminação.

Artigo VIII. Todo homem tem direito a receber dos tribunais nacionais competentes remédio efetivo para os atos que violem os direitos fundamentais que lhe sejam reconhecidos pela constituição ou pela lei.

Artigo IX. Ninguém será arbitrariamente prêso, detido ou exilado. 
Artigo X. Todo homem tem direito, em plena igualdade, a uma justa e pública audiência por parte de um tribunal independente e imparcial, para decidir de seus direitos e deveres ou do fundamento de qualquer acusação criminal contra êle.

Artigo XI. 1. Todo homem acusado de um ato delituoso tem o direito de ser presumido inocente até que a sua culpalidade tenha sido provada de acôrdo com a lei, em julgamento público no qual lhe tenham sido asseguradas tôdas as garantias necessárias à sua defesa.

2. Ninguém poderá ser culpado por qualquer ação ou omissão que, no momento, não constituiam delito perante o direito nacional ou internacional. Também não será imposta pena mais forte do que aquela que, no momento.da prática, era aplicável ao ato delituoso.

Artige XII. Ninguém será sujeito a interferências na sua vida privada, na sua família, no seu lar ou na sua correspondência, nem a ataques à sua honra e reputação. Todo homem tem direito à proteção da lei contra tais interferências ou ataques.

Artigo XIII. 1. Todo homem tem direito à liberdade de locomoção e residência dentro das fronteiras de cada Estado.

2. Todo homem tem o direito de deixar qualquer país, inclusive o próprio, e a êste regressar.

Artigo XIV. 1. Todo homem, vítima de perseguição, tem o direito de procurar e de gozar asilo em outros países.

2. Êste direito não pode ser invocado em caso de perseguição legitimamente motivada por crimes de direito comum ou por atos contrários aos objetivos e princípios das Nações Unidas.

Artigo XV. 1. Todo homem tem direito a uma nacionalidade.

2. Ninguém será arbitràriamente privado de sua nacionalidade, nem do direito de mudar de nacionalidade.

Artigo XVI. 1. Os homens e mulheres de maior idade, sem qualquer restrição de raça, nacionalidade ou religião, têm o direito de contrair matrimônio e fundar uma família. Gozam de iguais direitos em relação ao casamento, sua duração e sua dissolução.

2. O casamento não será válido senão com o livre e pleno consentimento dos nubentes.

3. A família é o núcleo natural e fundamental da sociedade e tem direito à proteção da sociedade e do Estado.

Artigo XVII. 1. Todo homem tem direito à propriedade, só ou em sociedade com outros.

2. Ninguém será arbitràriamente privado de sua propriedade. 
Artigo XVIII. Todo homem tem direito à liberdade de pensamento, consciência e religião; êste direito inclui a liberdade de mudar de religião ou crença e a liberdade de manifestar essa religião ou crença, pelo ensino, pela prática, pelo culto e pela observância, isolada ou coletivamente, em público ou em particular.

Artigo XIX. Todo homem tem direito à liberdade de opinião e expressão; êste direito inclui a liberdade de, sem interferências, ter opiniões e de procurar, receber e transmitir informações e idéias por quaisquer meios $e$ independentemente de fronteiras.

Artigo XX. 1. Todo homem tem direito à liberdade de reunião e associação pacíficas.

2. Ninguém pode ser obrigado a fazer parte de uma associação.

Atrigo XXI. 1. Todo homem tem o direito de tomar parte no govêrno de seu país diretamente ou por intermédio de representantes livremente escolhidos.

2. Todo homem tem igual direito de acesso ao serviço público do seu país.

3. A vontade do povo será a base da autoridade do govêrno; esta vontade será expressa em eleições periódicas e legítimas, por sufrágio universal, por voto secreto ou processo equivalente que assegure a liberdade de voto.

Artigo XXII. Todo homem, como membro da sociedade, tem direito à segurança social, e à realização, pelo esfôrço nacional, pela cooperação internacional e de acôrdo com a organização e recursos de cada Estado, dos direitos econômicos, sociais e culturais indispensáveis à sua dignidade a ao livre desenvolvimento da sua personalidade.

Artigo XXIII. 1. Todo homem tem direito ao trabalho, à livre escolha de emprêgo, a condições justas e favoráveis de trabalho e à proteção contra o desemprêgo.

2. Todo homem, sem qualquer distinção, tem direito a igual remuneração por igual trabalho.

3. Todo homem que trabalha tem direito a uma remuneração justa e satisfatória, que lhe assegure, assim como à sua família, uma existência compatível com a dignidade humana, e a que se acrescentarão, se necessário, outros meios de proteção social.

4. Todo homem tem direito a organizar sindicatos e a nêles ingressar para proteção de seus interêsses.

Artigo XXIV. Todo homem tem direito a repouso e lazer, inclusive à limitação razoável das horas de trabalho e a férias remuneradas periódicas. 
Artigo XXV. 1. Todo homem tem direito a um padrão de vida capaz de assegurar a si e a sua família saúde e bem-estar, inclusive alimentação, vestuário, habitação, cuidados médicos e os serviços sociais indispensáveis, e direito à segurança em caso de desemprêgo, doença, invalidez, viuvez, velhice ou outros casos de perda dos meios de subsistência em circunstâncias fora de seu contrôle.

2. A maternidade e a infância têm direito a cuidados e assistências especiais. Tôdas as crianças, nascidas dentro ou fora do matrimônio, gozarão da mesma proteção social.

Artigo XXVI. 1. Todo homem tem direito à instrução. A instrução será gratuita, pelo menos nos graus elementares e fundamentais. A instrução técnico-profissional será acessível a todos, bem como a instrução superior, esta baseada no mérito.

2. A instrução será orientada no sentido do pleno desenvolvimento da personalidade humana e do fortalecimento do respeito pelos direitos do homem e pelas liberdades fundamentais. A instrução promoverá a compreensão, a tolerância e a amizade entre tôdas as nações e grupos raciais ou religiosos, e coadjuvará as atividades das Nações Unidas em prol da manutenção da paz.

3. Os pais têm prioridade de direito na escolha do gênero de instrução que será ministrada a seus filhos.

Artigo XXVII. 1. Todo homem tem o direito de participar livremente da vida cultural da comunidade, de fruir as artes e de participar do progresso científico e de seus benefícios.

2. Todo homem tem direito à proteção dos interêsses morais e materiais decorrentes de qualquer produção científica, literária ou artística da qual seja autor.

Artigo XXVIII. Todo homem tem direito a uma ordem social e internacional em que os direitos e liberdades estabelecidos na presente Denlaração possam ser plenamente realizados.

Artigo XXIX. 1. Todo homem tem deveres para com a comunidade, na qual o livre e pleno desenvolvimento de sua personalidade é possível.

2. No exercício de seus direitos e liberdades, todo homem estará sujeito apenas às limitações determinadas pela lei, exclusivamente com 0 fim de assegurar o devido reconhecimento e respeito dos direitos e liberdades de outrem e de satisfazer às justas exigências da moral, da ordem pública e do bem-estar de uma sociedade democrática.

3. Êsses direitos e liberdades não podem, em hipótese alguma, ser exercidos contràriamente aos objetivos e princípios das Nações Unidas.

Artigo XXX. Nenhuma disposição da presente Declaração pode ser interpretada como o reconhecimento a qualquer Estado, grupo ou pessoa, do direito de exercer qualquer atividade ou praticar qualquer ato destinado à destruição de quaisquer dos direitos e liberdades aqui estabelecidos. 